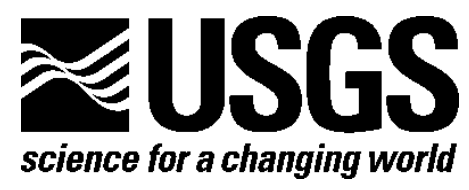

\title{
Preliminary Atlas of Active Shallow Tectonic Deformation in the Puget Lowland, Washington
}

Compiled by

Elizabeth A. Barnett, Ralph A. Haugerud, Brian L. Sherrod, Craig S. Weaver, Thomas L. Pratt, and Richard J. Blakely

Open-File Report 2010-1149

2010

U.S. Department of the Interior

U.S. Geological Survey 


\title{
U.S. Department of the Interior \\ KEN SALAZAR, Secretary
}

\author{
U.S. Geological Survey \\ Marcia K. McNutt, Director
}

U.S. Geological Survey, Reston, Virginia 2010

For product and ordering information:

World Wide Web: http://www.usgs.gov/pubprod

Telephone: 1-888-ASK-USGS

For more information on the USGS-the Federal source for science about the Earth, its natural and living resources, natural hazards, and the environment:

World Wide Web: http://www.usgs.gov

Telephone: 1-888-ASK-USGS

Suggested citation: Barnett, Elizabeth A., Haugerud, Ralph A., Sherrod, Brian L., Weaver, Craig S., Pratt, Thomas L., and Blakely, Richard J., compilers, 2010, Preliminary atlas of active shallow tectonic deformation in the Puget Lowland, Washington: U.S. Geological Survey Open-File Report 2010-1149, 32 p., 14 maps [http://pubs.usgs.gov/of/2010/1149/].

Any use of trade, product, or firm names is for descriptive purposes only and does not imply endorsement by the U.S. Government.

Although this report is in the public domain, permission must be secured from the individual copyright owners to reproduce any copyrighted material contained within this report. 


\section{Contents}

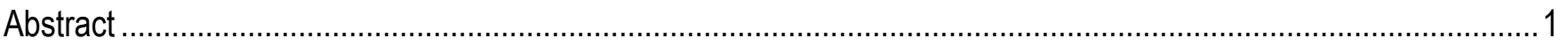

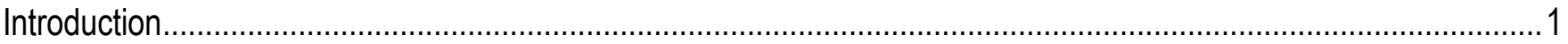

The Puget Lowland Geology and Geography and the Atlas Map Area .......................................................2

Tectonic Framework of Puget Lowland Shallow Faults....................................................................................

Active Faults Identified by Recent Geophysical and Geological Field Projects ......................................................

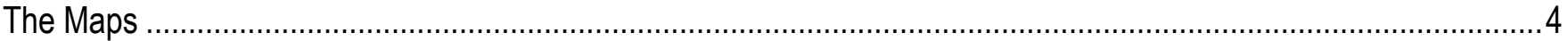

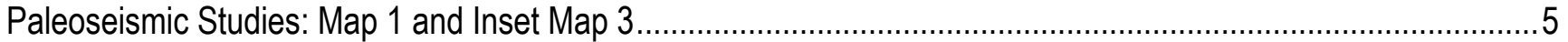

Seismic Reflection and Refraction Surveys: Map 2 and Inset Map 4 ..............................................................5

Thickness of Unconsolidated Quaternary Deposits: Map 5 and Inset Map 6 ....................................................5

Aeromagnetic Anomalies and Residual Aeromagnetic Anomalies: Maps 7 and 8 and

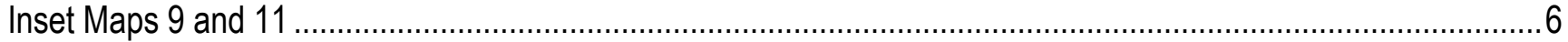

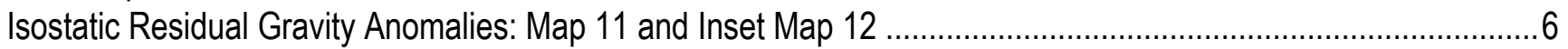

Active Shallow Fault Locations: Confluence of Geological and Geophysical Data ..............................................

Summary of Shallow Crust Deformation Data and Quaternary Fault Traces: Map 13 and Inset Map 14 ............... 7

Recently Identified Active Shallow Faults in Puget Lowland: Paleoseismic and Geophysical Evidence.................. 7

Southeastern Olympic Peninsula: Saddle Mountain Fault Zone, Canyon River Fault and Frigid

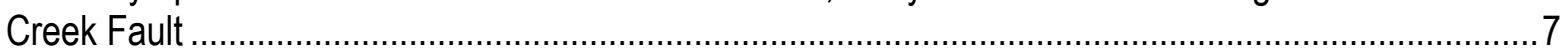

Southern and Central Puget Lowland: Seattle, Tacoma, and Olympia Faults ................................................. 8

South Whidbey Island Fault Zone (SWIF) .........................................................................................

North Puget Lowland: Darrington-Devils Mountain, Utsalady Point, Strawberry Point and Boulder

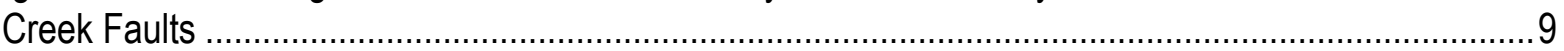

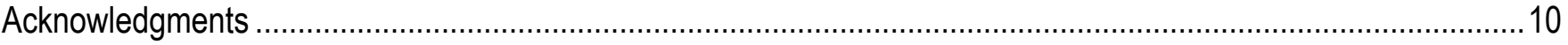

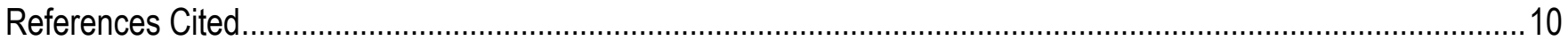

\section{Figures}

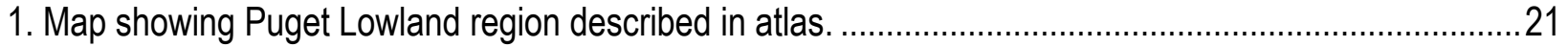

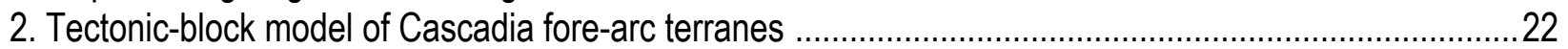

3. Map showing GPS velocities derived from continuous and campaign survey sites................................23

4. Map showing inferred Quaternary fault structures in Puget Lowland mapped before 1985 .....................24

5. Map showing Quaternary fault traces, including active Fault Zones, mapped before 2009 in the

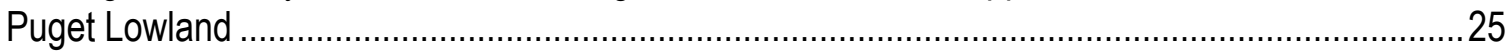

6. Map showing LiDAR-modeled coseismic shoreline uplift from A.D. 900-930 Seattle Fault

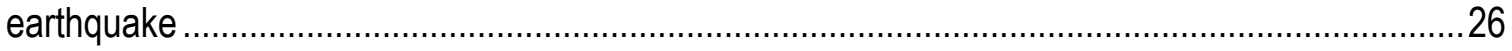

7. Schematic depiction of how data layers from atlas have been compiled in summary maps ....................27

8. Diagram of known ground-surface deformation in Puget Lowland caused by earthquakes on shallow faults since end of last glaciation 


\section{Tables}

1. References for faults and paleoseismic studies featured in atlas.

2. Trench excavations, fault scarps, and references.

Maps
\begin{tabular}{|l|l|}
\hline Map 1: Paleoseismic Studies in Puget Lowland \\
Map 2: Seismic Survey Locations in Puget Lowland \\
Inset Map 3: Paleoseismic Studies in Seattle/Tacoma Region \\
Inset Map 4: Seismic Survey Locations in Seattle/Tacoma Region \\
Map 5: Thickness of Unconsolidated Quaternary Deposits in Puget Lowland \\
Inset Map 6: Thickness of Unconsolidated Quaternary Deposits in Seattle/Tacoma Area \\
Map 7: Aeromagnetic Anomalies in Puget Lowland \\
Map 8: Residual Aeromagnetic Anomalies in Puget Lowland \\
Inset Map 9: Aeromagnetic Anomalies in Seattle/Tacoma Region \\
Inset Map 10: Residual Aeromagnetic Anomalies in Seattle/Tacoma Region \\
Map 11: Isostatic Residual Gravity Anomalies in Puget Lowland \\
Inset Map 12: Isostatic Residual Gravity Anomalies in Seattle/Tacoma Region \\
Map 13: Summary of Shallow Fault Deformation Data and Quaternary Fault Traces, Draped over \\
Residual Aeromagnetic Anomalies \\
Inset Map 14: Summary of Shallow Fault Deformation Data and Quaternary Fault Traces, Draped \\
over Residual Aeromagnetic Anomalies \\
\hline
\end{tabular}




\section{Abstract}

This atlas presents an up-to-date map compilation of the geological and geophysical observations that underpin interpretations of active, surface-deforming faults in the Puget Lowland, Washington. Shallow lowland faults are mapped where observations of deformation from paleoseismic, seismic-reflection, and potential-field investigations converge. Together, results from these studies strengthen the identification and characterization of regional faults and show that as many as a dozen shallow faults have been active during the Holocene. The suite of maps presented in our atlas identifies sites that have evidence of deformation attributed to these shallow faults. For example, the paleoseismic-investigations map shows where coseismic surface rupture and deformation produced geomorphic scarps and deformed shorelines. Other maps compile results of seismic-reflection and potential-field studies that demonstrate evidence of deformation along suspected fault structures in the subsurface. Summary maps show the fault traces derived from, and draped over, the datasets presented in the preceding maps. Overall, the atlas provides map users with a visual overview of the observations and interpretations that support the existence of active, shallow faults beneath the densely populated Puget Lowland.

\section{Introduction}

Research during the last quarter century accounts for nearly all of what is known today about the locations, paleoseismic histories, and damage potential of shallow faults that rupture the ground surface in the Puget Lowland, northwest Washington. In 1985, when Gower and others summarized geological and geophysical evidence for the region's shallow faults, only one of these structures, the Saddle Mountain Fault Zone, had demonstrated earthquake activity during the Holocene, or past 10,000 years (Carson, 1973; Wilson and others, 1975, 1979). Today, recent investigations show that there might be as many as a dozen shallow faults that have been active during the Holocene, which together heighten the seismic hazard of the Puget Lowland. These faults, as well as those considered to have been active during at least the Quaternary (the past 1.6 million years), are compiled in the U.S. Geological Survey Quaternary Fault and Fold Database (http://earthquake.usgs.gov/regional/qfaults/), an online database and map resource for fault traces and their source studies.

The primary motive behind producing this atlas is to present in map view both the active, surface-deforming shallow faults in the Puget Lowland and a compilation of the geological field and geophysical observations that underpin their interpretations and locations. By doing so, the atlas updates the Gower and others (1985) map and complements the U.S. Geological Survey Quaternary Fault and Fold Database. Although we include Quaternary faults in this atlas, here we emphasize currently known or suspected faults that have Holocene displacements and present their primary supporting geophysical and geological data evidence. These active and potentially active faults critically impact earthquake hazards in the densely populated metropolitan areas of the Puget Lowland.

The suite of maps is thematically organized, beginning with field evidence for coseismic fault-generated surface deformation and followed by geophysical subsurface observations of potentially related fault structures. In the final summary maps, deformation observations from the preceding maps are compiled and stacked; fault traces are then draped over the observations that support their interpretations. The maps listed below are more thoroughly described in the sections that follow: 
- Map 1 and Inset Map 3: Paleoseismic Studies

- Map 2 and Inset Map 4: Seismic Surveys and Locations

- Map 5 and Inset Map 6: Thickness of Unconsolidated Quaternary Deposits

- Map 7 and Inset Map 9: Aeromagnetic Anomalies

- Map 8 and Inset Map 10: Residual Aeromagnetic Anomalies

- Map 11 and Inset Map 12: Isostatic Residual Gravity Anomalies

Map 13 and Inset Map 14: Summary of Shallow Fault Deformation Data and Quaternary

Faults Traces Draped Over Residual Aeromagnetic Anomalies

\section{The Puget Lowland Geology and Geography and the Atlas Map Area}

The Puget Lowland is a north-south-trending structural basin that is flanked by Mesozoic and Tertiary rocks of the Cascade Range on the east and by Eocene rocks of the Olympic Mountains on the west. Quaternary glaciations and subsequent fluvial systems have shaped the basin by leaving behind a thick blanket of sediments (fig. 1) (Tabor and others, 1978, 1993, 2000; Shuster and others, 2005). The Puget Lowland encompasses this formerly glaciated plain, which fringes the surrounding mountains and contains Puget Sound and the eastern part of the Strait of Juan de Fuca. In order to include recent shallow fault studies located outside the lowland (fig. 1), we include in the map area of the atlas the east half of the Olympic Mountains, the west part of the Cascade Range, and the south part of the Georgia Strait. Thus, in the atlas, we define the Puget Lowland as the map area shown in figure 1.

\section{Tectonic Framework of Puget Lowland Shallow Faults}

Active shallow faults accommodate regional north-south shortening in the Puget Lowland. Situated near the north end of the Cascadia fore arc, the lowland is subject to tectonic compression as mobile fore-arc blocks migrate northward between the Cascade volcanic arc to the east and the convergent margin of the Cascadia Subduction Zone (CSZ) to the west (fig. 2) (Wells and others, 1998). Oblique subduction of the Juan de Fuca oceanic plate beneath the North America continental plate drives the Oregon Coast fore-arc block northward, compressing western Washington against the relatively stationary backstop of the British Columbia Coast Mountains (fig. 2) (Wells and others, 1998; Wells and Simpson, 2001).

GPS studies show that, between northern Oregon and Canada, the fore-arc blocks are rotating clockwise and translating northward at about 6 to $8 \mathrm{~mm} / \mathrm{yr}$ (fig. 3) (Wells and others, 1998; Wells and Simpson, 2001; Mazzotti and others, 2002). Within the Puget Lowland, GPS data record north-south shortening rates of from 3.0 to $4.0 \mathrm{~mm} / \mathrm{yr}$ (red arrows in fig. 3) (Mazzotti and others, 2002, 2003) to $4.4 \mathrm{~mm} / \mathrm{yr}$ (McCaffrey and others, 2007) after the interseismic loading signal (green and black arrows in fig. 3) of the locked CSZ is removed. The accumulated strain of this shortening is released by large earthquakes on the shallow east-west- to northwestsoutheast-trending faults and also accommodated in folds that traverse the Puget Lowland (figs. $4,5)$.

Gower and others (1985) delineated some of the Puget Lowland shallow fault zones (fig. 4) on the basis of geophysical and geological field observations that were available in the early 1980's. Gower and others (1985) noted that, although the majority of recorded earthquakes originate within the North America continental crust at depths less than $35 \mathrm{~km}$, earthquake hypocenters do not correlate well with inferred fault locations (fig. 4). Furthermore, researchers 
at that time had not yet studied the suspected shallow faults in enough detail to determine whether or not they were currently active.

More recent paleoseismic studies, however, have demonstrated that shallow faults in the Puget Lowland have produced large, surface-deforming Holocene earthquakes (maps 1, 3; table 1). In addition, geophysical investigations have better contrained the locations of these faults in the subsurface (maps 7-12; table 1). Earthquake histories for several of these Puget Lowland faults have emerged from paleoseismic investigations of deformed shorelines, marsh subsidence or uplift, tsunami deposits, liquefaction features, and fault scarps (maps 1, 3; tables 1, 2). Faults for which paleoseismic studies have documented Holocene activity are shown with solid black lines on figure 5 and maps 13, 14 (see fig. 5 and table 1 for references); dashed black lines indicate faults that either have documented earlier Pleistocene deformation or, at most, suspected Holocene activity.

\section{Active Faults Identified by Recent Geophysical and Geological Field Projects}

Recent advances documenting Puget Lowland shallow fault activity have resulted from both large, collaborative research initiatives and smaller, independent studies. The USGS Urban Hazards Studies program provides support for aeromagnetic, gravity, and seismic reflection and refraction experiments to map the Puget Lowland subsurface structure and better resolve the location and geometry of underlying faults. Large-scale studies include a highresolution aeromagnetic survey that extends from Olympia north to the Canadian border and from the Cascade Range foothills west to the east edge of the Olympic Mountains (maps 7-10) (Blakely and others, 1999), as well as a detailed set of seismic reflection and refraction surveys acquired between 1997 and 2002. These seismic experiments, called Seismic Hazards Investigations of Puget Sound (SHIPS), consist of marine surveys within Puget Sound, the Strait of Georgia, and the Strait of Juan de Fuca (map 2) (Brocher and others, 1999; Fisher and others, 1999); an onshore-offshore, 112-km-long two-dimensional seismic refraction/reflection line across the Seattle Basin (Brocher and others, 2000b); a dense passive seismic array that took advantage of the Seattle Kingdome implosion as a seismic source (Brocher, 2002); and two deep-borehole seismic-site-characterization studies in Seattle (Odum and others, 2004).

The large geophysical experiments conducted in the urban area coincided with the acquisition of over 10,000 square kilometers of high-resolution digital topographic data, known as LiDAR (Light Detection And Ranging) (map 1; see summary in Haugerud, 2003; see also, Puget Sound Lidar Consortium, http://pugetsoundlidar.ess.washington.edu/). LiDAR data processing removes the dense forest cover characteristic of the Pacific Northwest, allowing geologists to "see through the trees" and revealing a high-resolution image of the bare-earth ground surface. Subtle surface features such as fault scarps become visible at the centimeter scale of LiDAR imagery.

Pre-LiDAR field investigations documented active crustal faults such as the Saddle Mountain Fault Zone, in the southeastern Olympic Mountains (Wilson and others, 1975, 1979), and the Seattle Fault Zone (fig. 5) (Atwater and Moore, 1992; Bucknam and others, 1992; Jacoby and others, 1992; Karlin and Abella, 1992; Schuster and others, 1992; Sherrod and others, 2001). The arrival of LiDAR imaging, however, greatly facilitated the pinpointing of fault-related surface features such as individual fault scarps. These initial pre-LiDAR findings, in addition to 
the availability of LiDAR data, prompted several new fault investigations throughout the Puget Lowland (Haugerud, 2003).

Subsequent trench excavations of geomorphic scarps along inferred Holocene faults, some of which were already noted by Gower and others (1985) (fig. 4), and some of which were more recently discovered (fig. 5), have demonstrated that many of these faults have been active in the Holocene (table 2). Results from these Puget Lowland paleoseismic studies, including studies of coastal deformation and paleoecology, extended the currently known active faults from the Canadian border south to Olympia. Puget Lowland faults, summarized on maps 13 and 14 and also table 1, are, from north to south: the Boulder Creek Fault, the Utsalady Point Fault, the Lake Creek-Boundary Creek Fault (also known as the Little River Fault), the DarringtonDevils Mountain Fault, the Southern Whidbey Island Fault Zone (SWIF), the Seattle Fault Zone (SFZ), the Tacoma Fault Zone, the Saddle Mountain Fault Zone, the Frigid Creek Fault, and the Canyon River Fault (Wilson and others, 1979; Atwater and Moore, 1992; Bucknam and others, 1992; Johnson and others, 1996; Sherrod, 1998, 2001; Sherrod and others, 2001, 2002;

Haugerud, 2003; Nelson and others, 2003b; Johnson and others, 2004b; Kelsey and others, 2004; Sherrod and others, 2004a; Hughes, 2005; Walsh and others, 2007; Barnett, 2007; Nelson and others, 2007; Sherrod and others, 2008; Blakely and others, 2009; Personius, 2009; Witter and others, 2009; see also, tables 1 and 2 for additional references).

The integration of geophysical and geological field observations of deformation provides a rich dataset that serves to better characterize the locations, geometry, and earthquake histories for shallow faults in the Puget Lowland (table 1). For example, recent studies of the SFZ, the SWIF, the Tacoma Fault Zone, and the Saddle Mountain Fault Zone link subsurface-fault structures mapped from seismic and potential-field surveys to surface-deformation features identified in LiDAR and geological field data (Blakely and others, 2002; Nelson and others, 2003b; Johnson and others, 2004c; Sherrod and others, 2004a, 2008; Blakely and others, 2009).

\section{The Maps}

The atlas contains seven 1:600,000-scale maps of the Puget Lowland that depict various types of investigations and fault-generated deformation evidence. In, addition, 1:400,000-scale inset map follows each map. The larger scale maps provide greater detail of the most densely populated region of the Puget Lowland, which also has the greatest seismic risk, the SeattleTacoma region. The resolution of all PDF map files is sufficient for onscreen display and printing of finer scale details at larger scales. In order to provide visual and spatial continuity throughout the maps, some features such as fault scarps (orange lines) and trench locations (stars) appear on all maps, as do geographic boundaries and place names. Earthquakes, which have been recorded regionally since 1970, are continual reminders that the Puget Lowland region is seismically active (Pacific Northwest Seismic Network, 2008; www.pnsn.org). Shallow (depths less than $35 \mathrm{~km}$ ) earthquakes larger than magnitude 4 are featured on all maps. (In addition, figure 4 shows epicenters of earthquakes recorded since 1970 as small as, as well as magnitude 2 and focal mechanisms for larger events.) Summary maps 13 and 14 show currently known shallow fault traces draped over residual aeromagnetic anomalies.

It is important to note that, except where faults have ruptured or deformed the ground surface, fault traces drawn on the maps are not pinpoint locations. Instead, many fault traces are based on ongoing projects and only represent inferred and, in some cases, approximate locations of where fault planes either intersect or are thought to project to the ground surface. Thus, the fault traces on these maps should be used only as guides to the general locations of currently 
identified active fault zones and should not be used for site-specific evaluations of potential earthquake hazards.

\section{Paleoseismic Studies: Map 1 and Inset Map 3}

Map 1 and inset map 3 depict fault-related surface deformation features along with the locations of trenches excavated across LiDAR-identified fault scarps. (See table 2 for the trench study names, the sense of fault motion, and the references that describe trench excavations.) Current sources of LiDAR survey data are shown in the maps, as are locations of shoreline studies and directions of observed shoreline subsidence or uplift was observed (Bucknam and others, 1992; Bucknam, 1999; Sherrod, 2001, 2004a). Also shown on inset map 3 are data from a LiDAR-based model of regional marine-terrace uplift during the A.D. 900 SFZ earthquake, which indicates that the region experienced as much as $8.5 \mathrm{~m}$ of coseismic uplift near the southern tip of Bainbridge Island (see also, fig. 6) (Bucknam and others, 1992; Muller and Harding, 2005).

\section{Seismic Reflection and Refraction Surveys: Map 2 and Inset Map 4}

By imaging the subsurface, seismic reflection profiles can reveal the deeper structure of the Puget Lowland. Although fault planes are not clearly distinguishable in the seismic reflection profiles, imaging of deformed strata can be used to infer the subsurface locations of shallow faults that deform the ground surface (table 1).

Map 2 and inset map 4 depict the locations of both marine seismic surveys and land profiles. Also shown are the projected surface traces of faults that are based on deformed strata observed in the marine seismic reflection profiles (Johnson and others, 1996; Pratt and others, 1997; Johnson and others, 1999, 2001b, 2004c).

Until recently, marine seismic reflection profiles from Puget Sound and the Strait of Juan de Fuca provided the majority of subsurface information on fault structures that cross the Puget Lowland (Pratt and others, 1997; Brocher and others, 1999; Fisher and others, 1999; Johnson and others, 1999; Brocher and others, 2001; Johnson and others, 2004c; Dash and others, 2007; see also, table 1 for additional references). Recent land-based seismic reflection studies of the SFZ and SWIF have extended the marine-survey imaging of the fault zones onto land, as indicated on map 2 and inset map 4 (Brocher and others, 2000b, 2002; Stephenson and others, 2006; Liberty and others, 2008; Sherrod and others, 2008).

\section{Thickness of Unconsolidated Quaternary Deposits: Map 5 and Inset Map 6}

The Puget Lowland contains thick Quaternary-age deposits, most of which are derived from the advance and retreat of repeated glacial episodes that covered the region, overprinted by modern fluvial and marine processes. Jones (1996) compiled a point dataset of measured and inferred thicknesses of unconsolidated deposits throughout the Puget Lowland from nearly 4,000 water, oil, coal, and gas well logs and 700 seismic reflection shot sites. Where wells do not reach bedrock, the deepest wells in the area provide a minimum thickness; in addition, Jones (1996) interpolated a regional maximum thickness on the basis of nearby wells that do penetrate bedrock. Deposit thicknesses vary from a thin veneer, on the Puget Lowland margins along the Olympic and Cascade Mountains, to more than 1-km thick, in the Seattle and Everett Basins.

Map 5 and inset map 6 depict contours of deposit thickness and well locations from Jones (1996). Also shown is a generalized bedrock surface derived from the Jones (1996) point data that depicts a simplified image of the Puget Lowland stripped of its thick layer of unconsolidated 
deposits. Jones' (1996) interpolation accounts for any discrepancies between the point data and the contours and color shading-relief.

Locations where deposits are thin along the northern and southern margins of the Seattle and Everett Basins coincide with the locations of inferred active fault structures (see also, fig. 5 and maps 13 and 14). Subsequent seismic reflection studies indicate that these basins are structurally bounded by faults (Pratt and others, 1997; Brocher and others, 2001; Johnson and others, 2004c). The thick deposits of the Seattle Basin are located at the northern boundary of the SFZ, and the Everett Basin is bounded by the SWIF and the Utsalady Point and Strawberry Point faults (maps 13 and14).

\section{Aeromagnetic Anomalies and Residual Aeromagnetic Anomalies: Maps 7 and 8 and Inset Maps 9 and 10}

Potential-field observations provide another means to constrain subsurface fault locations and geometries. Faults that juxtapose rocks that have contrasting magnetic properties produce small magnetic fields near the topographic surface that can be detected with airborne magnetic surveys. Magnetic anomaly maps derived from such surveys provide a way to map faults covered by vegetation, water, or young geologic materials. Maps 7 through 10 show a highresolution aeromagnetic survey of the Puget Sound region conducted in 1997 (Blakely and others, 1999, 2002). Map 7 and inset map 9 show the original data; map 8 and inset map 10 show the original data reprocessed to emphasize magnetic anomalies originating from shallow magnetic sources by filtering out deeper source anomalies.

Maps 7 and inset map 9 show the location of abrupt magnetization contrasts, informally called "maxspots," as estimated from magnetic anomalies using potential-field geophysical software (Blakely and Simpson, 1986). These maxspots form lineaments, some of which mark the location of shallow faults, as indicated by the spatial association between magnetic lineaments and fault scarps shown on maps 7 and 9.

\section{Isostatic Residual Gravity Anomalies: Map 11 and Inset Map 12}

Along with magnetic observations, some gravity anomalies observed in the Puget Lowland indicate possible faults and fault-bounded structural basins. Map 11 and inset map 12 show isostatic residual gravity anomalies that are based on the compilation of Finn and others (1991). Isostatic residual gravity anomalies (Simpson and others, 1986) reflect density of the middle and upper crust. Gravity gradients are present where rocks of contrasting densities are juxtaposed, such as along fault zones; therefore, they are particularly useful for defining sedimentary basins and their bounding faults. The Seattle, Everett, and Tacoma Basins appear in map 11 as broad gravity lows that reflect the relatively low density of basin-filling sedimentary rocks. Also depicted on map 11 and inset map 12 are the locations of sharp density contrasts, also called maxspots, estimated from gravity anomalies (Blakely and Simpson, 1986). For example, a sharp gravity gradient located along the southern margin of the Seattle Basin marks the Seattle Fault.

The spatial density of gravity measurement stations varies throughout the Puget Lowland; accordingly, the data resolution varies. To show this visually, the locations of the gravity stations are depicted on map 11 and inset map 12, and areas of greater station spatial density reflect higher resolution data (Finn and others, 1991). For example, the highest resolution gravity data on these maps cover the region within the Puget Sound between Victoria, B.C., and Tacoma. 


\section{Active Shallow Fault Locations: Confluence of Geological and Geophysical Data}

\section{Summary of Shallow Crust Deformation Data and Quaternary Fault Traces: Map 13 and Inset Map 14}

Shallow faults in the Puget Lowland are mapped where multiple geophysical and geological observations of crustal deformation converge. Together, these observations bolster the identification and characterization of potentially damaging faults and provide a rich database of surface- and subsurface-deformation evidence from geological field surveys (map 1 and inset map 3), seismic reflection profiles (map 2 and inset map 4), structural basin boundaries (map 5 and inset map 6), and potential-field anomaly gradients (maps 7 through 12). In summary maps 13 and 14, deformation observations from maps 1 through 12 have been compiled and stacked; fault traces are then draped over the observations that underpin their characterizations.

For example, figure 7 schematically shows the construction of the summary maps and the array of deformation evidence that constrain the mapping of surface fault traces such as the SFZ. As depicted by data layers in figure 7 and throughout maps 1 through 12, multiple fault-scarp excavations and shoreline-deformation studies quantify surficial Holocene deformation located above sharp magnetic- and gravity-anomaly gradients and above deformed subsurface seismic strata. The SFZ also bounds the edge of the deepest structural basin in the Puget Lowland, the Seattle Basin. North of the Seattle Fault Zone, trench excavations of LiDAR-identified fault scarps, subsurface stratigraphic deformation recognized in seismic reflection profiles, and magnetic-anomaly gradients constrain the location of the SWIF (Sherrod and others, 2008).

These faults and most other Puget Lowland fault traces are differentiated between those that have demonstrated Holocene activity and those for which evidence for Holocene activity is inconclusive but Quaternary activity is suspected (fig. 5; maps 13 and 14). Most Puget Lowland fault traces are from the USGS Quaternary Fault and Fold Database (http://earthquake.usgs.gov/regional/qfaults/), but we have updated several fault traces using work completed since its publication: the South Whidbey Island Fault (SWIF) strands have been mapped farther east across the Puget Sound toward the Cascade Range (Blakely and others, 2004; Sherrod and others, 2005a, 2005b, 2008); the Tacoma Fault also has been extended farther east (Johnson and others, 2004c; Brocher and others, 2001; Sherrod and others, 2004a, 2004b); and the Boulder Creek Fault is a newly recognized fault near the Canadian border (Haugerud, 2005; Barnett, 2007; Barnett and others, 2007; Siedlecki, 2007) (fig. 5; maps 13 and 14; table 1). In addition, the USGS Quaternary Fault and Fold Database does not list the Olympia Fault, but we have included it here as a subject of ongoing research (fig. 5; maps 13 and 14; table 1) (Blakely and others, 1999; Sherrod, 2001).

\section{Recently Identified Active Shallow Faults in Puget Lowland: Paleoseismic and Geophysical Evidence}

Southeastern Olympic Peninsula: Saddle Mountain Fault Zone, Canyon River Fault and Frigid Creek Fault

The Saddle Mountain Fault scarps provide the earliest clear indications of fault-related surface deformation in the Puget Lowland (see Tables 1 and 2 for information of specific faults) (Carson, 1973; Wilson and others, 1975, 1979). After identifying fault scarps on aerial 
photographs of clear cut timberland, Wilson and others (1979) excavated trenches across these scarps and sampled drowned trees from neighboring wetlands for radiocarbon-dating material. Their early work and more recent trenching and wetland studies demonstrate that Holocene reverse faulting created the scarps and submerged an adjacent forest as recently as 1,000 years ago (Wilson and others, 1979; Hughes, 2005; Witter and others, 2009). A ground-magnetic survey supported the presence of east-side-up fault structures beneath the Saddle Mountain Fault Zone that might relate to the observed deformation features (Blakely and others, 2005, 2009).

Other fault scarps that flank the east side of the Olympic Mountains corroborate recent tectonic deformation. Trench excavations across the Canyon River (Walsh and others, 2007), Frigid Creek (Blakely and others, 2009), and Lake Creek-Boundary Creek/Little River Fault scarps (Nelson and others, 2007) confirm Holocene activity along these faults. Blakely and others (2009) suggested that, on the basis of paleoseismic work and aeromagnetic-data analysis, these fault zones form an en echelon chain of active fault segments along the east edge of the Olympic Mountains. Moreover, they might compose the western fault boundary of the SFZ and, thus, be components of the deformation zone that accomodates shortening in the Puget Lowland (Blakely and others, 2009).

\section{Southern and Central Puget Lowland: Seattle, Tacoma, and Olympia Faults}

Underlying the urban areas of Seattle and Tacoma, the Seattle Uplift (fig. 4; maps 13, 14) is a wedge of uplifted crust situated between two active fault zones (Gower structures I and $\mathrm{K}$ on figs. 4 and 5; see also SFZ and Tacoma Fault Zone on maps 13, 14): the SFZ to the north, interpreted as a south-dipping reverse fault that separates the Seattle Basin from the Seattle Uplift (Yount, 1992; Bucknam and others, 1992; Pratt and others, 1997; Johnson and others, 1999; Blakely and others, 2002; Nelson and others, 2003b; Brocher and others, 2004a); and the north-dipping, reverse Tacoma Fault Zone to the south (Sherrod and others, 2004). Observations, measurements, and radiocarbon dates from earthquake-triggered features demonstrate Holocene deformation along the Seattle and Tacoma Fault Zones include the following: fault scarps on Bainbridge Island (Nelson and others, 2003b), Waterman Point (Nelson and others, 2003a), Vasa Park (Sherrod, 2002), Catfish Lake (Sherrod and others, 2004a, 2004b), Sunset Beach (Nelson and others, 2007), and Saddle Mountain (Hughes and others, 2005; Witter and others, 2009); coastal uplift (maps 1, 3) (Bucknam, 1992; Sherrod, 2001; Sherrod and others, 2002, Sherrod and others, 2004a; Muller and others, 2006; Ota and others, 2006); landslides (Jacoby and others, 1992); and turbidites in Lake Washington (Karlin and Abella, 1992, 1996), and tsunami deposits (Atwater and Moore, 1992).

The most recent uplift event that occurred around 1,100 years ago (A.D. 900-930) probably produced most of the Seattle Uplift deformation features (Atwater and Moore, 1992; Bucknam and others, 1992; Atwater, 1999). A large earthquake, possibly magnitude 7 or greater (Bucknam and others, 1992; Pratt and others, 1997; Muller and Harding, 2005; ten Brink, 2006) uplifted shorelines within the SFZ (Bucknam and others, 1992), caused subsidence of the Seattle Basin north of the fault, and triggered a tsunami in Puget Sound (Atwater and Moore, 1992) (fig. 5; maps 1,3). On the south edge of the Seattle Uplift, warped shorelines and intertidal marshes that straddle the Tacoma Fault also recorded regional uplift north of the Tacoma Fault and subsidence south of the fault around 1,100 years ago (Bucknam and others, 1992; Sherrod and others, 2002, 2004a, 2004b).

Recent seismic-reflection and aeromagnetic studies helped to constrain subsurface geometry of the Seattle and Tacoma Fault Zones. Seismic reflection profiles image subsurface 
deformation attributed to the SFZ (maps 2, 4, 13, 14) (Pratt and others, 1997; Johnson and others, 1999; Liberty and Pratt, 2008) and the Tacoma Fault Zone (Pratt and others, 1997; Brocher and others, 2001; Johnson and others, 2004c). Because of large offsets, the fault zones also appear as linear anomalies in gravity (map 11) and aeromagnetic data (map 7) (Gower and others, 1985; Blakely and others, 2002) and as velocity anomalies in seismic-tomography results (Brocher and others, 2001).

Still farther south, a prominent northwest-southeast-trending aeromagnetic anomaly south of Olympia (map 7) and evidence for abrupt submergence of a southern Puget Sound marshland and forest about 1,100 years ago (maps 2,13) suggest the approximate location of the inferred Olympia Fault (structure labeled "L" in fig. 4) (Blakely and others, 1999; Sherrod, 2001). No fault scarps have been found above this structure, and, other than a broad zone of inferred deformation, the location of the fault trace remains poorly known.

Paleoseismic evidence collected throughout the Puget Lowland indicates that several faults described above may have ruptured during or around the time of the A.D. 900-930 event. Figure 8 shows age ranges of earthquakes on shallow faults throughout the Puget Lowland and the apparent cluster around this event.

\section{South Whidbey Island Fault Zone (SWIF)}

North of the SFZ, the SWIF cuts across central and northern Puget Lowland (structure labeled ' $G$ ' in fig. 4, 5; map 13) as a possible transpressional fault (Johnson and others, 1996). The SWIF, located by marine seismic-reflection and aeromagnetic data (Johnson and others, 1996), extends from offshore Vancouver Island southeastward nearly $100 \mathrm{~km}$ and projects onto land. Blakely and others (2004) and Sherrod and others (2005a, 2005b, 2008; maps 7, 9, 13) mapped the fault strands about another $40 \mathrm{~km}$ southeastward toward the Cascade Mountains by modeling aeromagnetic-anomaly data and excavating LiDAR-identified fault scarps. A coastaluplift study on Whidbey Island (Kelsey and others, 2004) and surface-rupture studies conducted northeast of Seattle (Sherrod and others, 2008) documented at least four earthquakes along the eastern extension of SWIF within the past 16,000 years. Two of the youngest occurred between 3,200 and 2,800 years ago and less than 2,700 years ago (Kelsey and others, 2004; Sherrod and others, 2008).

\section{North Puget Lowland: Darrington-Devils Mountain, Utsalady Point, Strawberry Point, and Boulder Creek Faults}

The Darrington-Devils Mountain, Utsalady Point, and Strawberry Point Faults might compose elements of an active oblique-slip transpressional deformation zone between southeastern Vancouver Island and the Cascade Range foothills (structure labeled "A" in figs. 4, 5; Map 13) (Johnson and others, 2001b, 2004b). Trench studies of scarps located along the Darrington-Devils Mountain (Personius and others, 2009) and Utsalady Point Faults indicate that Holocene faulting generated these scarps (map 1). Trench excavations across the Utsalady Point Fault scarps indicate that the fault ruptured at least once, and possibly twice, during the last 2000 years (Johnson and others, 2004b).

Recent paleoseismic work northwest of Mount Baker has shifted the previously mapped, northernmost limit of active shallow faults over $50 \mathrm{~km}$ north, from the Darrington-Devils Mountain Fault Zone to just south of the Canadian border. Excavations of LiDAR-identified fault scarps along the mapped trace of the Boulder Creek Fault (map 13) (Misch, 1966), as well as coring of adjacent wetlands, has yielded evidence of three or more Holocene oblique-thrusting 
events (Haugerud and others, 2005; Barnett, 2007; Barnett and others, 2007). Subsequent trenching (for example, the Smuggler trench) along nearby en echelon fault scarps also has demonstrated faulting (map 1; table 2). Just south of the Boulder Creek fault, Dragovich and others (1997a, 1997b) attribute the 1990 Deming earthquake swarm (Qamar and Zollweg, 1990) (fig. 4) to activity along the Macaulay Creek Thrust Fault (map 13) on the basis of field evidence and earthquake data collected during the swarm. No surface rupture, however, was identified, and so Holocene activity along the thrust fault remains unresolved.

\section{Acknowledgments}

We would like to thank the following people for providing both data and advice: Tom Brocher, USGS (seismic data); Wes Thelan, PNSN (mapGMT help); Todd Williams, Pacific Plate Boundary Observatory (PBO data); Ray Wells, U.S. Geological Survey (GPS data and figures); Jordan Muller (shoreline data); Renate Hartog and Jon Connolly, PNSN (data); Diana Martinez, Puget Sound Regional Council (LiDAR information); Stephane Mazzotti, Pacific Geoscience Centre (GPS data); and very helpful and informative content reviews from Joan Gomberg, Katie Keranen, and Brian Atwater of U.S. Geological Survey

\section{References}

Anderson, M.L., Dragovich, J.D., Blakely, R.J., Wells, R., and Brocher, T.M., 2008, Where Does the Seattle Fault End? Structural Links and Kinematic Implications [abs.]: Eos Transactions, American Geophysical Union, Fall Meeting Supplement, v. 89, no. 53, p. F2535.

Atwater, B.F., and Moore, A.L., 1992, A tsunami about 1000 years ago in Puget Sound, Washington: Science, v. 258, p. 1614-1617.

Atwater, B.F., 1999, Radiocarbon dating of a Seattle earthquake to A.D. 900-930 [abs.]: Seismological Research Letters Abstracts with Programs, v. 70, p. 232.

Babcock, R.S., Burmester, R.F., Engebretson, D.C., Warnock, A., and Clark, K.P., 1992, A rifted margin origin for the Crescent basalts and related rocks in the northern Coast Range province, Washington and British Columbia: Journal of Geophysical Research, v. 97, no. B5, p. 6799-6821.

Barnett, E.A., Kelsey, H.M., Sherrod, B.L., Blakely, R.J., Hughes, J.F., Schermer, E.R., Haugerud, R.A., Weaver, C.S., and Siedlecki, E., 2006, Active faulting at the northeast margin of the greater Puget Lowland: a paleoseismic and magnetic-anomaly study of the Kendall scarp, Whatcom County, Northwest Washington [abs.]: Eos Transactions, American Geophysical Union, Fall Meeting Supplement, v. 87, no. 52, p. F1672.

Barnett, E.A., 2007, Active faulting at the Northwest margin of the Greater Puget Lowland: A trenching and wetland coring study of the Kendall fault scarp, Whatcom County, Washington: Arcata, Humboldt State University, M.S. Thesis, 65 p., 1 plate. http://humboldt-dspace.calstate.edu/xmlui/handle/2148/158

Barnett, E., Kelsey, H., Sherrod, B., Hughes, J., Schermer, E., Haugerud, R., Weaver, C., Siedlecki, E., and Blakely, R., 2007, Active faulting at the northeast margin of the Greater Puget Lowland: A trenching and wetland coring study of the Kendall fault scarp, Whatcom County, Northwest Washington: Geological Society of America Abstracts with Programs (Cordilleran Section), v. 39, no. 4, p. 61. 
Barnett, E. A., Sherrod, B. L., Kelsey, H. M., Czajkowski, J. L., Walsh, T. L., Contreras, T. A., Davis-Stanton, K., Schermer, E. R., and Carson, R.J., 2009, Active Faulting Along the Saddle Mountain fault zone, Southeast Olympic Mountains, WA [abs.]: Eos Transactions, American Geophysical Union, Fall Meeting Supplement, v. 90, no. 52, Abstract S51B-1404.

Blakely, R. J., and Simpson, R.W., 1986, Approximating edges of source bodies from magnetic or gravity anomalies: Geophysics, v. 51, p. 1494-1498.

Blakely, R.J., Wells, R.E., and Weaver, C.S., 1999, Puget Sound aeromagnetic maps and data: U.S. Geological Survey Open-File Report 99-514, http://pubs.usgs.gov/of/1999/of99$514 /$.

Blakely, R.J., Wells, R.E., Weaver, C.S., and Johnson, S.Y., 2002, Location, structure, and seismicity of the Seattle fault, Washington--Evidence from aeromagnetic anomalies, geologic mapping, and seismic-reflection data: Geological Society of America Bulletin, v. 114, no. 2, p. 169-177.

Blakely, R. J., Sherrod, B. L., Wells, R. E., Weaver, C. S., McCormack, D. H., Troost, K. G., and Haugerud, R. A., 2004, The Cottage Lake Aeromagnetic Lineament: A Possible Onshore Extension of the Southern Whidbey Island Fault, Washington: U.S. Geological Survey Open-File Report 2004-1204, 35 p.

Blakely, R.J., Hughes, J.F., Sherrod, B.L., and Wells, R.E., 2005, Hunting the Saddle Mountain fault zone in the Olympic Peninsula with airplane and canoe [abs.]: Eos Transactions, American Geophysical Union, Fall Meeting Supplement, v. 86, no. 52, p. F1438.

Blakely, R.J., Sherrod, B.L., Hughes, J.F., Anderson, M.L., Wells, R.E., and C.S. Weaver, 2009, The Saddle Mountain Fault, Olympic Peninsula, Washington: Western Boundary of the Seattle Uplift: Geosphere, v.5, no.2, p. 105-125.

Booth, D.B., Troost, K.G., and Shimel, S., 2003, Landfall of the Seattle fault zone, west Seattle, WA [abs.]: Geological Society of America Abstracts with Programs (Annual Meeting), v.35, no.6, p. 479.

Booth, D.B., Troost, K.G., and Shimel, S.A., 2005, Geologic map of northwestern Seattle (part of the Seattle North 7.5' x 15' quadrangle), King County, Washington: U.S. Geological Survey Scientific Investigations Map 2903, scale 1:12,000.

Bourgeois, J., and Johnson, S.Y., 2001, Geologic evidence of earthquakes at the Snohomish delta, Washington, in the past 1200 years: Geological Society of America Bulletin, v. 113, p. 482-494.

Brocher, T.M., Parsons, T., Creager, K.C., Crosson, R.S., Symons, N.P., Spence, G.D., Zelt, B.C., Hammer, P.T.C., Hyndman, R.D., Mosher, D.C., Trehu, A.M., Miller, U.S., Fisher, M.A., Pratt, T.L., Alvarez, M.G., Beaudoin, B.C., Louden, K.E., and Weaver, C.S., 1999, Wide-angle seismic recordings from the 1998 seismic hazards investigation of Puget Sound (SHIPS), western Washington and British Columbia: U. S. Geological Survey Open-File Report 99-314, 110 p.

Brocher, T.M., Miller, K.C., Tréhu, A.M., Snelson, C.M., Pratt, T.L., Weaver, C.S., Creager, K.C., Crosson, R.S., ten Brink, U.S., Alvarez, M.G., Harder, S.H., and Asudeh, I., 2000a: Report for explosion and earthquake data acquired in the 1999 Seismic Hazards Investigation of Puget Sound (SHIPS), Washington: U.S. Geological Survey Open-File Report 2000-318, 85 p. 
Brocher, T.M., Pratt, T.L., Creager, K.C., Crosson, R.S., Steele, W.P., Weaver, C.S., Frankel, A.D., Trehu, A.M., Snelson, C.M., Miller, K.C., Harder, S.H., and ten Brink, U.S., 2000b, Urban seismic experiments investigate Seattle fault and basin [abs.]: Eos

Transactions, American Geophysical Union, Fall Meeting Supplement, v. 81, p. 551-552.

Brocher, T.M., Parsons, T., Blakely, R.J., Christensen, N.I., Fisher, M.A., Wells, R.E., and SHIPS Working Group, 2001, Upper crustal structure in Puget Lowland, Washington-Results from the 1998 seismic hazards investigation in Puget Sound: Journal of Geophysical Research, v. 106, p. 13,541-13,564.

Brocher, T.M., Pratt, T.L., Weaver, C.S., Snelson, C.M., and Frankel, A.D., 2002, Seismic recordings from the 2000 Kingdome Seismic Hazards Investigation in Puget Sound (SHIPS), Washington: U.S. Geological Survey Open-File Report 02-123, 29 p.

Brocher, T.M., Pratt, T.L., Spence, G.D., Reidel, M., and Hyndman R.D., 2003, Wide-angle seismic recordings from the 2002 Georgia Basin geohazards initiative, northwestern Washington and British Columbia, U. S. Geological Survey Open-File Report 03-160, 35 p.

Brocher, T.M., Blakely, R.J., and Wells, R.E., 2004a, Interpretation of the Seattle uplift, Washington, as a passive roof duplex: Bulletin of Seismological Society of America, v. 94, p.1379-1401.

Brocher, T.M., Sherrod, B.L., Johnson, S.Y., Blakely, R.J., and Lidke, D.J., compilers, 2004b, Fault number 581, Tacoma fault: Quaternary fault and fold database of the United States, accessed 02/10/2008, at http://earthquakes.usgs.gov/regional/qfaults.

Brown, R.D., Jr., Gower, H.D., and Snavely, P.D., Jr., 1960, Geology of the Port Angeles-Lake Crescent area, Clallam County, Washington: U.S. Geological Survey Oil and Gas Investigations Map OM-203, scale 1:62,500.

Brown, E.H., 1987, Structural geology and accretionary history of the northwest Cascades system, Washington and British Columbia: Geological Society of America Bulletin, v. 99, p. 201-214.

Bucknam, R.C., Hemphill-Haley, E., and Leopold, E.B., 1992, Abrupt uplift within the past 1700 years at southern Puget Sound, Washington: Science, v. 258, p. 1611-1614.

Bucknam, R.C., compiler, 1999, Atlas of reconnaissance data from paleoseismic studies of the Puget Sound region, Washington: U.S. Geological Survey Web Page, http://earthquake.usgs.gov/regional/pacnw/paleo/atlas.html, accessed Oct., 2007.

Bucknam, R.C., Sherrod, B.L., and Elfendahl, G., 1999, A fault scarp of probable Holocene age in the Seattle fault zone, Bainbridge Island, Washington: Seismological Research Letters, v. 258, p. 1611-1614.

Calvert, A.J., Fisher, M.A., and SHIPS Working Group, 2001, Imaging the Seattle fault zone with high-resolution seismic tomography: Geophysical Research Letters, v. 28, p. 23372340 .

Carson, R.J., 1970, Quaternary geology of the south-central Olympic Peninsula, Washington: Seattle, University of Washington, Ph.D. dissertation, 67 p.

Carson, R.J., 1973, First known active fault in Washington: Washington Geologic Newsletter: Washington Division of Geology and Earth Resources, v. 1, no. 3, p. 1-2.

Cuellar, Oscar, 1994, Geophysical evidence for the Hood Canal Fault and its implications on tectonics of the Puget Sound region, WA: Seattle, University of Washinton, Undergraduate Thesis, $25 \mathrm{p}$. 
Czajkowski, J.L., Walsh, T.J., Contreras, T.A., Davis-Stanton, K., Kelsey, H.M., Schermer, E.R., and Carson, R.J., 2009, Active faulting along a newly-found segment of the Saddle Mountain fault zone, southeastern Olympic Mountains, WA: A paleoseismic trenching study [abs.]: Geological Society of America Abstracts with Programs, v. 41, no. 7, p. 479.

Danes, Z.F., Bonno, M., Brau, E., Gilham, W.D., Hoffman, T.F., Johansen, D., Jones, M,H., Malfait, B., Masten, J., and Teague, G.O., 1965, Geophysical investigation of the southern Puget Sound area, Washington: Journal of Geophysical Research, v. 70, p. 5573-5579.

Dash R.K., Spence G.D., Riedel M., Hyndman R.D., and Brocher T.M., 2007, Upper-crustal structure beneath the Strait of Georgia, Southwest British Columbia: Geophysical Journal International v. 170 , no. 22 , p. 800-812.

Dragovich, J.D., Haugerud, R.A., Norman, D.K., and Pringle, P.T., 1997a, Geologic map of the Kendall and Deming 7.5-minute quadrangles, western Whatcom County, Washington: Washington Division of Geology and Earth Resources Open-File Report 97-2, 39 p., 3 pls., scale 1:24,000.

Dragovich, J.D., Zollweg, J.E., Qamar, A.I., and Norman, D.K., 1997b, The Macaulay Creek thrust, the 1990 5.2-magnitude Deming earthquake, and Quaternary geologic anomalies in the Deming area, western Whatcom County, Washington--Cause and effects?: Washington Geology, v. 25, no. 2, p. 15-27.

Dragovich, J.D., Logan, R.L., Schasse, H.W., Walsh, T.J., Lingley, W.S., Jr., Norman, D.K., Gerstel, W.J., Lapen, T.J., Schuster, J.E., and Meyers, K.D., 2002, Geologic map of Washington--Northwest quadrant: Washington Division of Geology and Earth Resources Geologic Map GM-50, 72 p., 3 pls., scale 1:250,000.

Dragovich, J.D. and DeOme, A.J., 2006, Geologic map of the McMurray 7.5-minute quadrangle, Skagit and Snohomish Counties, Washington, with a discussion of the evidence for Holocene activity on the Darrington-Devils Mountain fault zone, scale 1:24,000: Washington Division of Geology, GM-61, 18 p., 1 plate, scale 1:24,000.

Dragovich, J.D., 2007, The Darrington-Devils Mountain fault-A probable active reverse oblique slip fault zone in Skagit and Island counties, Washington [abs.]: Geological Society of America Abstracts with Programs (Cordilleran Section), v. 39, no. 4, p.26.

Dragovich, J.D. and Stanton, B.W., 2007, The Darrington-Devils Mountain fault-A probably active reverse-oblique-slip fault zone in Skagit and Island Counties, Washington: Washington Department of Natural Resources Open-File Report, OFR 2007-2, 2 plates, scale 1:31,104.

Finn, C., Phillips, W.M., and Williams, D.L., 1991, Gravity anomaly and terrain maps of Washington: U.S. Geological Survey Geophysical Investigations Map GP-988, scale 1:500,000 and 1:1,000,000.

Fisher, M.A., Brocher, T.M., Hyndman, R.D., Trehu, A.M., Weaver, C.S., Creager, K.C., Crosson, R.S., Parsons, T., Cooper, A.K., Mosher, D., Spence, G., Zelt, B.C., Hammer, P.T., tenBrink, U., Pratt, T.L., Miller, K.C., Childs, J.R., Cochrane, G.R., Chopra, S., and Walia, R., 1999, Seismic survey probes urban earthquake hazards in Pacific Northwest: EOS, v. 80, no. 2, p. 13-17.

Gower, H.D., 1980, Bedrock geologic and Quaternary tectonic map of the Port Townsend area, Washington: U.S. Geological Survey Open-File Report 80-1174, 19 p., scale 1:100,000. 
Gower, H.D., Yount, J.C., and Crosson, R.S., 1985, Seismotectonic map of the Puget Sound region, Washington: U.S. Geological Survey Miscellaneous Investigations Map I-1613, 15 p., scale 1:250,000.

Haeussler, P.J., Wells, R.E., Blakely, R.J., Murphy, J., and Wooden, J.L., 2000, Structure and timing of movement on the Seattle fault at Green and Gold Mountains, Kitsap Peninsula, Washington: Geological Society of America Abstracts with Programs, v. 32, no. 6, p. A16.

Haug, B.J., 1998, High resolution seismic reflection interpretations of the Hood Canal-Discovery Bay fault zone; Puget Sound, Washington: Portland, Portland State University, M.S. Thesis, $102 \mathrm{p}$.

Haugerud, R.A., Weaver, C.S., and Harless, J., 2001, Finding faults with LIDAR in the Puget Lowland: Seismological Research Letters, v. 72, p. 253.

Haugerud, R.A., 2002, Lidar evidence for Holocene surface rupture on the Little River fault near Port Angeles, Washington: Seismological Research Letters, v. 73, no. 2.

Haugerud, R.A., Harding, D.J., Johnson, S.Y., Harless, J.L., Weaver, C.S., and Sherrod, B.L., 2003, High-resolution lidar topography of the Puget Lowland, Washington--A bonanza for earth science: Geological Society of America GSA Today, v. 13, no. 6, p. 4-10.

Haugerud, R.A., Sherrod, B.L., Wells, R.E., and Hyatt, T., 2005, Holocene displacement on the Boulder Creek fault near Bellingham, Washington, and implications for kinematics of deformation of the Cascadia forearc [abs.]: Geological Society of America Abstracts with Programs, v. 37, p. 476.

Haugerud, R.A., and Tabor, R.W., 2008, Geomorphic Evidence for Multiple Large Post-glacial Earthquakes on the Western Seattle Fault [abs.]: Eos Transactions, American Geophysical Union, Fall Meeting Supplement, v. 89, no. 53, p. F2548.

Hayward, N., Nedimovic, M.R., Cleary, M., and Calvert, A.J., 2006, Structural variation along the Devil's Mountain fault zone, northwestern Washington: Canadian Journal of Earth Sciences, v. 43, p. 433-446.

Hughes, J.F. 2005, Meters of Synchronous Holocene Slip on two strands of a fault in the western Puget Sound Lowland, Washington [abs.]: Eos Transactions, American Geophysical Union, Fall Meeting Supplement, v. 86, no. 52, p. 1437.

Jacoby, G.C., Williams, P.L., and Buckley, B.M., 1992, Tree ring correlation between prehistoric landslides and abrupt tectonic events in Seattle, Washington: Science, v. 258, p. 16211623.

Johnson, S.Y., 1984. Stratigraphy, age and paleogeography of the Eocene Chukanut Formation, Northwest Washington: Canadian Journal of Earth Sciences, v. 21, p. 92-106.

Johnson, S.Y., Potter, C.J., and Armentrout, J.M., 1994, Origin and Evolution of the Seattle fault and Seattle basin: Geology, v. 22, p. 71-74 and oversize insert.

Johnson, S.Y., Potter, C.J., Armentrout, J.M., Miller, J.J., Finn, C., and Weaver, C.S., 1996, The southern Whidbey Island fault--An active structure in the Puget Lowland, Washington: Geological Society of America Bulletin, v. 108, p. 334-354 and oversize insert.

Johnson, S.Y., Dadisman, S.V., Childs, J.R. and Stanley, W.D., 1999, Active tectonics of the Seattle fault and central Puget Lowland: Implications for earthquake hazards: Geological Society of America Bulletin, v. 111, p. 1042-1053.

Johnson, S.Y., compiler, 2001, Fault number 571, Strawberry Point fault: Quaternary fault and fold database of the United States, accessed 02/10/2008, at http://earthquakes.usgs.gov/regional/qfaults. 
Johnson, S.Y., Blakely, R.J., and Brocher, T.M., compilers, 2001a, Fault number 574, Devils Mountain fault: Quaternary fault and fold database of the United States, accessed 02/10/2008, at http://earthquakes.usgs.gov/regional/qfaults.

Johnson, S.Y., Dadisman, S.V., Mosher, D.C., Blakely, R.J., and Childs, J.R., 2001b, Active tectonics of the Devils Mountain fault and related structures, northern Puget Lowland and eastern Strait of Juan de Fuca region, Pacific Northwest: U.S. Geological Survey Professional Paper 1643, 46 p., 2 plates.

Johnson, S.Y., Nelson, A.R., Personius, S.F., Wells, R.E., Kelsey, H.M., Sherrod, B.L., Okumura, K., Koehler, R., Witter, R, Bradley, L.-A., and Harding, D.J., 2003a, Maps and data from a trench investigation of the Utsalady Point fault, Whidbey Island, Washington, U.S. Geological Survey Miscellaneous Investigations Map 2420, 1 plate.

Johnson, S.Y., Blakely, R.J., and Brocher, T.M., compilers, 2003b, Fault number 573, Utsalady Point fault: Quaternary fault and fold database of the United States, accessed 02/10/2008, at http://earthquakes.usgs.gov/regional/qfaults.

Johnson, S.Y., compiler, 2004, Fault number 570, Seattle fault zone, in Quaternary fault and fold database of the United States: U.S. Geological Survey website, http://earthquakes.usgs.gov/regional/qfaults, accessed 02/10/2008 07:06 PM.

Johnson, S.Y., Blakely, R.J., Brocher, T.M., Sherrod, B.L., Lidke, D.J., and Kelsey, H.M., compilers, 2004a, Fault number 572, Southern Whidbey Island fault zone: Quaternary fault and fold database of the United States, accessed 02/10/2008, at http://earthquakes.usgs.gov/regional/qfaults.

Johnson, S.Y., Nelson, A.R., Personius, S.F., Wells, R.E., Kelsey, H.M., Sherrod, B.L., Okumura, K., Koehler, R. Witter, R.C., Bradley, L., and Harding, D.J., 2004b, Evidence for late Holocene earthquakes on the Utsalady Point fault, northern Puget Lowland, Washington: Bulletin of the Seismological Society of America, v. 94, p.2299-2316.

Johnson, S.Y., Blakely, R.J., Stephenson, W.J., Dadisman, S.V., and Fisher, M.A., 2004c, Active shortening of the Cascadia forearc and implications for seismic hazards of the Puget Lowland: Tectonics, v. 23, TC1011, doi:10.1029/2003TC001507, 27 p.

Jones, M.A., 1996, Thickness of unconsolidated deposits in the Puget Sound Lowland, Washington and British Columbia: U.S. Geological Survey Water Resources Investigations Report 94-4133,1 plate, scale 1:450,000.

Karel, P., and Liberty, L.M., 2008, The western extension of the Seattle fault: new insights from seismic reflection data [abs.]: Eos Transactions, American Geophysical Union, Fall Meeting Supplement, v. 89, no. 53, p. F2513.

Karlin, R.A., and Abella, S.E.A., 1992, Paleoearthquakes in the Puget Sound region recorded in sediments from Lake Washington, U.S.A.: Science, v. 258, p. 1617-1620.

Karlin, R.E., and Abella, S.E.A., 1996, A history of Pacific Northwest earthquakes recorded in Holocene sediments from Lake Washington, Journal of Geophysical Research, v. 101, no. B3, p. 6137-6150.

Kelsey, H.M., Sherrod, B.L., Johnson, S.Y., and Dadisman, S.V., 2004, Land-level changes from a late Holocene earthquake in the northern Puget Lowland, Washington: Geology, v. 32, p. 469-472.

Kelsey, H.M., Sherrod, B.L., Nelson, A.R., and Brocher, T.M., 2009, Earthquakes generated from bedding plane-parallel reverse faults above an active wedge thrust, Seattle fault zone: Geological Society of America Bulletin, v. 120, no. 11/12, p. 1581-1597. 
Liberty, L.M. and Pratt, T.L., 2007, Recent high-resolution seismic reflection studies of active faults in the Puget Lowland: Geological Society of America, Abstracts with Programs (Cordilleran Section), v 39, no. 4, p.61.

Liberty, L.M. and Pratt, T.L., 2008, Structure of the Eastern Seattle Fault Zone, Washington State: New Insights from Seismic Reflection Data: Bulletin of the Seismological Society of America, v. 98, no. 4, p. 1681-1695.

Lidke, D.J., compiler, 2003a, Fault number 552, Hood Canal fault zone: Quaternary fault and fold database of the United States, accessed 02/10/2008, at http://earthquakes.usgs.gov/regional/qfaults.

Lidke, D.J., compiler, 2003b, Fault number 554, Macaulay Creek thrust: Quaternary fault and fold database of the United States, accessed 02/10/2008, at http://earthquakes.usgs.gov/regional/qfaults.

Lidke, D.J., compiler, 2003c, Fault number 558, Canyon River fault: Quaternary fault and fold database of the United States, accessed 02/10/2008, at http://earthquakes.usgs.gov/regional/qfaults.

Lidke, D.J., compiler, 2003d, Fault number 575, Saddle Mountain faults: Quaternary fault and fold database of the United States, accessed 02/10/2008, at http://earthquakes.usgs.gov/regional/qfaults.

Lidke, D.J., compiler, 2003e, Fault number 556, Little River fault: Quaternary fault and fold database of the United States, accessed 02/10/2008, at http://earthquakes.usgs.gov/regional/qfaults.

Lovseth, T.P., 1975, The Devils Mountain fault zone, northwestern Washington: Seattle, University of Washington, unpub. M.S. Thesis, 29 p.

Luetgert, J., Mooney, W., Tréhu, A, Nabelek, J., Keller, G.R., Miller, K., Asudeh, I., and Isbell, B., 1993, Data report for a seismic refraction/wide-angle reflection investigation of the Puget Basin and Willamette Valley in western Washington and Oregon: U.S. Geological Survey Open-File Report, 93-347, 71 p.

Mazzotti, S., Dragert, H., Hyndman, R.D., Miller, M.M., and Henton, J.A., 2002, GPS deformation in a region of high crustal seismicity: North Cascadia forearc: Earth and Planet Science Letters, v. 198, p. $41-48$.

Mazzotti, S., Dragert, H., Henton, J., Schmidt, M., Hyndman, R., James, T., Lu, Y., and Craymer, M., 2003, Current tectonics of northern Casadia from a decade of GPS measurements: Journal of Geophysical Research, v. 108, no. B12, 18 p.

McCaffrey, R. Qamar, A., King, I., Wells, R. W., Khazaradze, R., Williams, G., Stevens, C. A., Vollick, C. W., and Zwick, J. J., 2007, Fault locking, block rotation and crustal deformation in the Pacific Northwest: Geophysical Journal International, v.169, p. 13151340.

Miller, K.C., Keller, G.R., Gridley, J.M., Luetgert, J.H., Mooney, W.D., and Thybo, H., 1997, Crustal structure along the west flank of the Cascades, western Washington: Journal of Geophyical Research, v. 102, p. 17,857-17,873.

Misch, P., 1966, Tectonic evolution of the northern Cascades of Washington State: Canadian Institute of Mining and Metallurgy Special Volume 8, p. 101-148.

Mitchell, M., Liberty, L.M., and Pratt. T.L., 2008, Segmentation of the Tacoma fault: evidence from seismic and magnetic data [abs.]:Eos Transactions, American Geophysical Union, Fall Meeting Supplement, v. 89, no. 53, p. F2513. 
Muller, J., and Harding, D., 2005, Mw = 7.2-7.4 estimated for A.D. 900 Seattle fault earthquake by modeling the uplift of a LIDAR-mapped marine terrace [abs.]: Eos Transactions, American Geophysical Union, Fall Meeting Supplement, v. 86, no. 52, p. F1438.

Nelson, A.R., Johnson, S.Y., Wells, R.E., Pezzopane, S.K., Kelsey, H.M., Sherrod, B.L., Bradley, L.-A., Koehler, Rick D. III, Bucknam, R.C., Haugerud, R.A., and Laprade, W.T., 2002, Field and laboratory data from an earthquake history study of the Toe Jam Hill fault, Bainbridge Island, Washington: U.S. Geological Survey Open File Report 020060, 2 pamphlets, 2 pls.

Nelson, A.R., Johnson, S.Y., Kelsey, H.M., Sherrod, B.L., Wells, R.E., Okumura, K., Bradley, L.-A., Bogar, R., and Personius, S.F., 2003a, Field and laboratory data from an earthquake history study of the Waterman Point fault, Kitsap County, Washington: U.S. Geological Survey Miscellaneous Field Studies Map MF-2423, 1 plate.

Nelson, A.R., Johnson, S.Y., Kelsey, H.M., Wells, R.E., Sherrod, B.L., Pezzopane, S.K., Bradley, L., Koehler, R.D., and Bucknam, R.C., 2003b, Late Holocene earthquakes on the Toe Jam Hill fault, Seattle fault zone, Bainbridge Island, Washington: Geological Society of America Bulletin, v. 115, p. 1388-1403.

Nelson, A.R., Personius, S.F., Buck, Jason, Bradley, L.-A., Wells, R.E., and Schermer, E.R., 2007, Field and laboratory data from an earthquake history study of scarps of the Lake Creek-Boundary Creek fault between the Elwha River and Siebert Creek, Clallam County, Washington: U.S. Geological Survey Scientific Investigations Map 2961, 2 sheets.

Odum, J.K., Stephenson, W.J., Goetz-Troost, K., Worley, D.M., Frankel, A.D., Williams, R.A., and Fryer, J., 2004, Shear - and Compressional- Wave Velocity Measurements from Two 150-m-Deep Boreholes in Seattle, Washington, USA: U.S. Geological Survey Open-File Report 2004-1419, 36 p.

Ota, Y., Odagiri, S., Sasaki, H., and Mukoyama, S., 2006, Late Holocene deformation as deduced from the former shoreline height of marine terraces above the Seattle fault zone, Washington state. Jishin, v. 58, no. 4, p. 385-399.

Personius, S.F., Nelson, A.R., Briggs, R.W., Maharrey, J.Z., Schermer, E.R., and Bradley, L.-A., in press, Lidar-assisted study of Holocene faulting on the Darrington-Devils Mountain fault zone, Western Washington [abs.]: Seismological Research Letters, v. 80,

Plate Boundary Observatory (PBO) data accessed from website, http://pboweb.unavco.org; GPS velocity solutions accessed Jan, 2008.

Pacific Northwest Seismic Network, 2008, www.pnsn.org.

Pratt, T.L., Johnson, S.Y., Potter, C.J., Stephenson, W.J., and Finn, C., 1997, Seismic Reflection Images beneath Puget Sound, Western Washington State: The Puget Lowland Thrust Sheet hypothesis, Journal of Geophysical Research, v. 102, no. B12, p. 27,469-27,489.

Pratt, T.L., 2008, Is Downtown Seattle on the Hanging Wall of the Seattle Fault? [abs.]:Eos Transactions, American Geophysical Union, Fall Meeting Supplement, v.89 no. 53, p. F2513.

Pratt and others, in prep.

Qamar, A.I., and Zollweg, J.E., 1990, The 1990 Deming, Washington earthquakes--A sequence of shallow thrust earthquakes in the Pacific Northwest [abs.]: Eos (American Geophysical Union Transactions), Fall Meeting Supplement, v. 71, no. 41, p. 1145. 
Rohwer, K. A., 1994, Evidence for the extension of the Seattle fault into the upper part of Hood Canal and Dabob Bay, WA, and formation of a tectonic model to explain the formation of the shallow seismic events in the Puget Sound local: Seattle, University of Washington, Undergraduate Thesis, $23 \mathrm{p}$.

Schuster, R.L., Logan, R.L., and Pringle, P.T., 1992, Prehistoric rock avalanches in the Olympic Mountains, Washington: Science, v. 258, pp. 1620-1621.

Schuster, J.E., 2005, Geologic map of Washington state: Washington Division of Geology and Earth Resources Geologic Map GM-53, 44 p., 1 sheet with pamphlet, scale 1:500,000.

Sherrod, B.L., 1998, Late Holocene environments and earthquakes in southern Puget Sound: Seattle, University of Washington, PhD dissertation, $159 \mathrm{p}$.

Sherrod, B.L., 2001, Evidence for earthquake-induced subsidence about 1100 years ago in coastal marshes of southern Puget Sound, Washington: Geological Society of America Bulletin, v. 113, p. 1299-1311.

Sherrod, B.L., Haeussler, P.J., Wells, R., Troost, K., Haugerud, R., 2001, Surface rupture in the Seattle fault zone near Bellevue, WA [abs.]: Seismological Research Letters, v.72, p. 253.

Sherrod, B.L., 2002, Late Quaternary surface rupture along the Seattle fault zone near Bellevue, Washington [abs.]: Eos Transactions, American Geophysical Union, v. 83, Fall Meeting Supplement, Abstract S21C-12.

Sherrod, B.L., Brocher, T.M., and Bucknam, R.C., 2002, Asynchronous land-level change along the Tacoma fault in A.D. 800-1200: Seismological Research Letters, v. 73, p. 240.

Sherrod, B.L., Brocher, T.M., Weaver, C.S., Bucknam, R.C., Blakely, R.J., Kelsey, H.M., Nelson, A.R., and Haugerud, R.A., 2004a, Holocene fault scarps near Tacoma, Washington, USA: Geology, v. 32, p. 9-12.

Sherrod, B.L., Nelson, A.R., Kelsey, H.M., Brocher, T.M., Blakely, R.J., Weaver, C.S., Rountree, N.K., Rhea, S.B., and Jackson, B.S., 2004b, The Catfish Lake Scarp, Allyn, Washington: Preliminary Field Data and Implications for Earthquake Hazards Posed by the Tacoma Fault: U.S. Geological Survey Open-File Report 03-455, 11 p., 1 plate.

Sherrod, B.L., Barnett, E., and Kelsey, H.M., 2005a, Excavation Logs of Two Trenches Across a Strand of the Southern Whidbey Island Fault Zone Near Grace, Washington: U.S. Geological Survey Open-File Report 2005-1013, 1 plate.

Sherrod, B.L., Blakely, R.J., Weaver, C., Kelsey, H., Barnett, E. and Wells, R., 2005b, Holocene fault scarps and shallow magnetic anomalies along the southern Whidbey Island fault zone near Woodinville, Washington: U.S. Geological Survey Open File Report, 2005$1136,35 \mathrm{p}$.

Sherrod, B.L., Blakely, R.J., Weaver, C.S., Kelsey, H.M, Barnett, E., Liberty, L., Meagher, K.L., and Pape K., 2008, Finding concealed active faults: Extending the southern Whidbey Island fault across the Puget Lowland, Washington: ournal of Geophysical Research, Volume 113, no. B5, 25 p.

Sherrod, B.L., Barnett, E.A., Schermer, E., Kelsey, H.M., Hughes, J., Foit, F., Weaver, C.S., Haugerud, R.A., and Hyatt, T., in review, Lidar geomorphology and active tectonics in the foothills of the North Cascades, Washington.

Siedlecki, E., 2007, Paleoseismology of the Boulder Creek fault, Kendall, WA: [abs.]: Geological Society of America Abstracts with Programs (Cordilleran Section), v. 39, no. 4, p. 26. 
Simpson, R. W., Jachens, R. C., Blakely, R. J., and Saltus, R. W., 1986, A new isostatic residual gravity map of the conterminous United States with a discussion of the significance of isostatic residual anomalies: Journal of Geophysical Research, v. 91, p. 8348-8372.

Stephenson, W.J., Frankel, A.D., Odum, J.K., Williams, R.A. and Pratt, T.L., 2006, Toward resolving an earthquake ground motion mystery in west Seattle, Washington State: Shallow seismic focusing may cause anomalous chimney damage: Geophysical Research Letters, v. 33, no. 6, p. L06316.

Tabor, R.W., and Cady, W.M., 1978, Geologic map of the Olympic Peninsula, Washington: U.S. Geological Survey Miscellaneous Investigations Series Map I-994,1 sheet, scale $1: 125,000$.

Tabor, R.W., Booth, D.B., Vance, J.A., Ford, A.B., and Ort, M.H., 1988, Preliminary geologic map of the Sauk River 30' by 60' quadrangle, Washington: U.S. Geological Survey OpenFile Report 88-692, scale 1:100,000.

Tabor, R.W., Frizzell, V.A., Jr., Booth, D.B., Waitt, R.B., Whetten, J.T. and Zartman, R.E., 1993, Geologic map of the Skykomish 60-minute by 30- minute quadrangle, Washington: U.S. Geological Survey Miscellaneous Investigations I-1963 Map, 42 p., 1 plate, scale $1: 100,000$.

Tabor, R.W., 1994, Late Mesozoic and possible early Tertiary accretion in western Washington state--The Helena-Haystack melange and the Darrington-Devils Mountain fault zone: Geological Society of America Bulletin, v. 106, p. 217-232.

Tabor, R.W., Frizzell, V.A, Jr, Booth, D.B., and Waitt, R.B., Jr., 2000, Geologic map of the Snoqualmie Pass 60 minute by 30 minute quadrangle, Washington: U.S. Geological Survey Miscellaneous Investigations I-2538, 75 p., scale 1:100,000.

ten Brink, U.S., Song, J., and Bucknam, R.C., 2006, Rupture models for the A.D. 900-930 Seattle fault earthquake from uplifted shorelines: Geology, v. 34, no. 7, p. 585-588.

Troost, K.G., 1994, Dating earthquakes, subsidence, and sea-level rise, using archaeological data at West Point, Seattle, Washington: Geological Society of America, Abstracts with Programs, v. 26, no. 7, p.157.

Troost, K.G., Booth, D.B., Wisher, A.P., and Shimel, S.A., 2005, The geologic map of Seattle A progress report, 2005, U. S. Geological Survey Open-File report 2005-1252, 1 sheet, scale $1: 24,000$.

Troost, K.G., in review, Geologic map of the Tacoma South 7.5-minute quadrangle, Washington: U.S. Geological Survey Miscellaneous Field Investigation, scale 1:24,000.

Troost, K.G., Booth, D.B., and Borden, R., in review, Geologic map of the Tacoma North 7.5minute quadrangle, Washington: U.S. Geological Survey Miscellaneous Field Investigation, scale 1:24,000.

U.S. Geological Survey, 2006, Quaternary Fault and Fold Database of the United States, http://earthquake.usgs.gov/regional/qfaults/.

Wagner, H.C., and Tomson, J.H., 1987, Offshore geology of the Strait of Juan de Fuca; State of Washington and British Columbia, Canada: Washington Division of Geology and Earth Resources Open-File Report 87-1, 16 p.

Walsh, T.J., and Logan, R.L., 1997, The Canyon River fault, an active fault in the southern Olympic Range, Washington: Washington Geology, v. 25, no. 4, p. 21-24.

Walsh, T.J., Logan, R.L., 2007, Field Data for a Trench on the Canyon River Fault, Southeast Olympic Mountains, Washington: Washington Department of Natural Resources Open File Report, 2007-1, I sheet. 
Wells, R.E., Weaver, C.S., and Blakely, R.J., 1998, Forearc migration in Cascadia and its neotectonic significance: Geology, v. 26., p. 759-762.

Wells, R.E. and Simpson, R.W., 2001, Northward migration of the Cascadia forearc in the northwestern U.S. and implications for subduction deformation: Earth, Planets, and Space, v.53, p. 275-283.

Whetten, J.T., Carroll, P.I., Gower, H.D., Brown, E.H., and Pessl, F., Jr., 1988, Bedrock geologic map of the Port Townsend 30' by 60' quadrangle, Puget Sound region, Washington: U.S. Geological Survey Miscellaneous Investigations Map I-1198-G, scale 1:100,000.

Wilson, J. R., 1975, Geology of the Price Lake area, Mason County, Washington: Raleigh, North Carolina State University, M.S. Thesis, 79 p.

Wilson, J.R., Bartholomew, M.J., and Carson, R.J., 1979, Late Quaternary faults and their relationship to tectonism in the Olympic Peninsula, Washington: Geology, v. 26, p. 235239.

Witter, R.C., Givler, R.W., Zeliff, M., Iacoboni, C., and Carson, R.J., 2006, Two post-glacial earthquakes on the Saddle Mountain West fault, southeastern Olympic Peninsula, Washington: U.S. Geological Survey, National Earthquake Hazard Reduction Program Final Report, 42 p., 2 pls.

Witter, R.C., Givler, R.W., and Carson, R.J., 2009, Two post-glacial Earthquakes on the Saddle Mountain West fault, southeastern Olympic Peninsula, Washington: Bulletin of the Seismological Society of America, v. 98, no. 6, p. 2894-2917.

Yount, J., 1992, The Seattle Fault; a possible Quaternary reverse fault beneath Seattle, Washington: Geological Society of America Abstracts with Programs, v. 24, p. 93. 


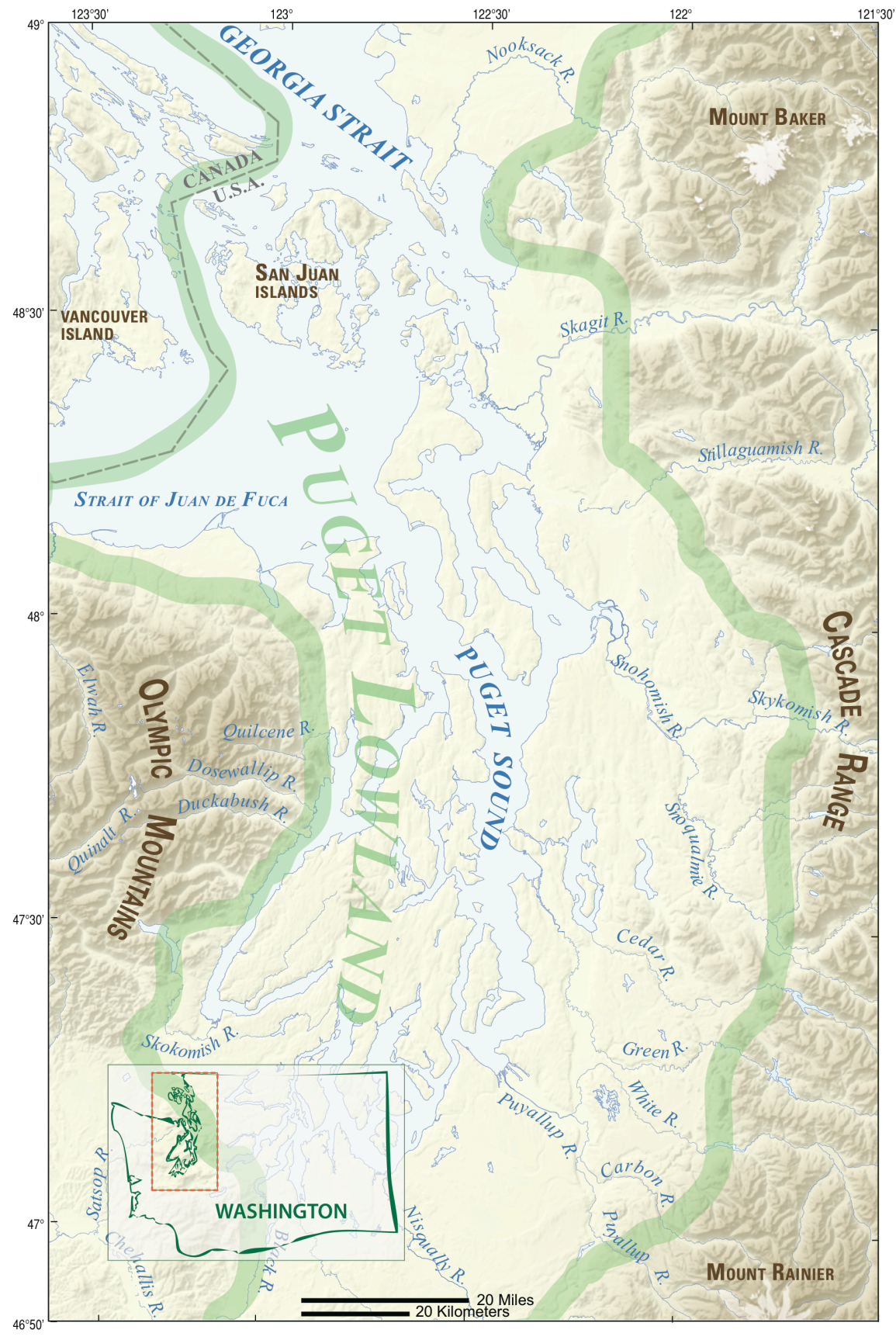

Figure 1. Map showing Puget Lowland region described in atlas, which includes Puget Lowland (green outline), eastern part of Olympic Mountains, western part of Cascade Range, and southern part of Georgia Strait. For simplicity and to incorporate most datasets relevant to shallow faults, in the text, Puget Lowland refers to the entire map extent shown in figure 1 and in maps. 


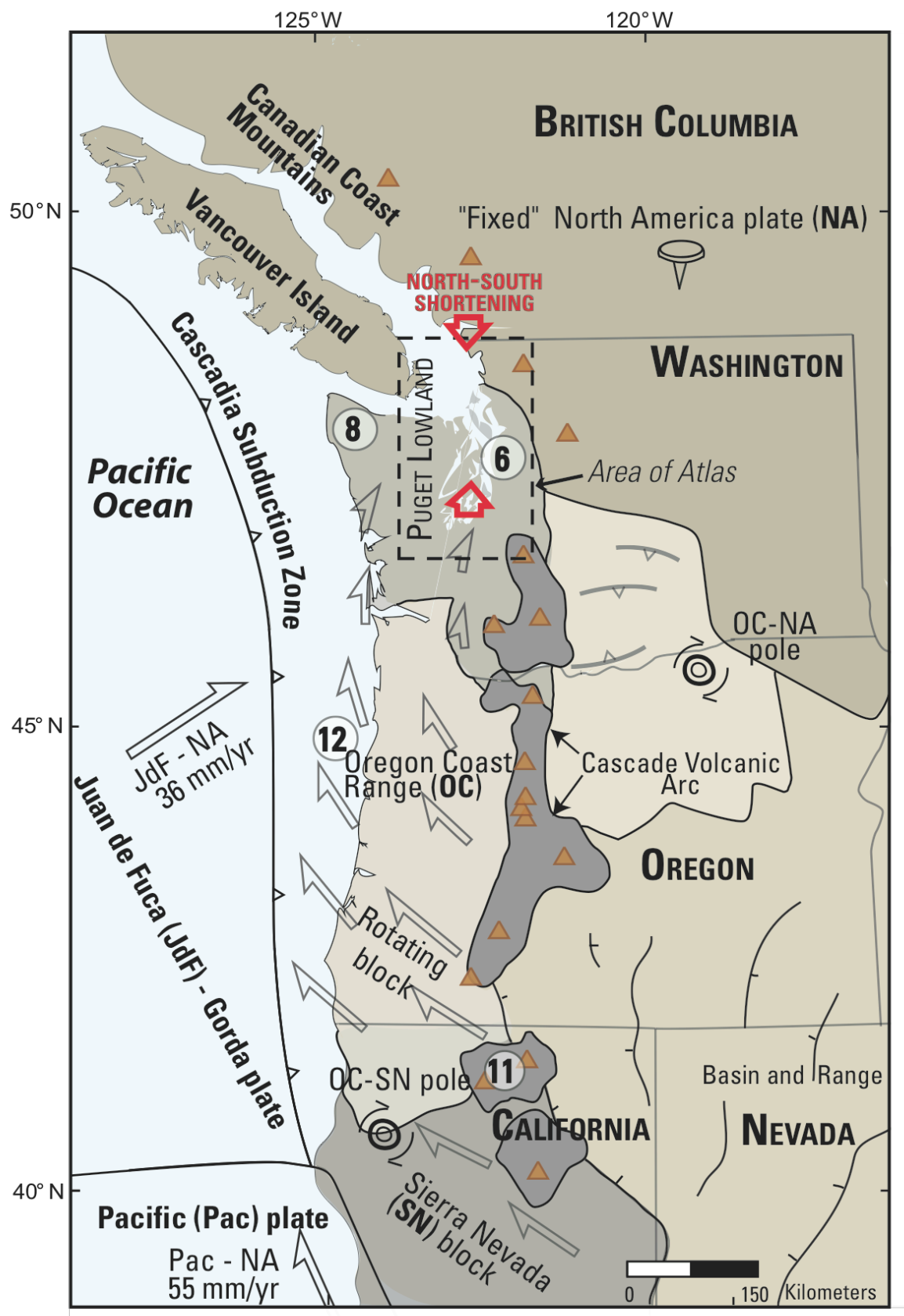

Figure 2. Tectonic-block model of Cascadia fore-arc terranes, modified from Wells and Simpson (2001) and Wells and others (1998). Gray arrows indicate relative plate motion. Block motion (circled numbers) is in $\mathrm{mm} / \mathrm{yr}$. Rotation of Sierra Nevada block and of Oregon Coast Range block about their respective Euler poles induce north-south shortening of western Washington against backstop of the Canadian Coast Mountains. Red arrows indicate north-south shortening of Puget Lowland region. Orange triangles denote Cascade Arc volcanoes. 


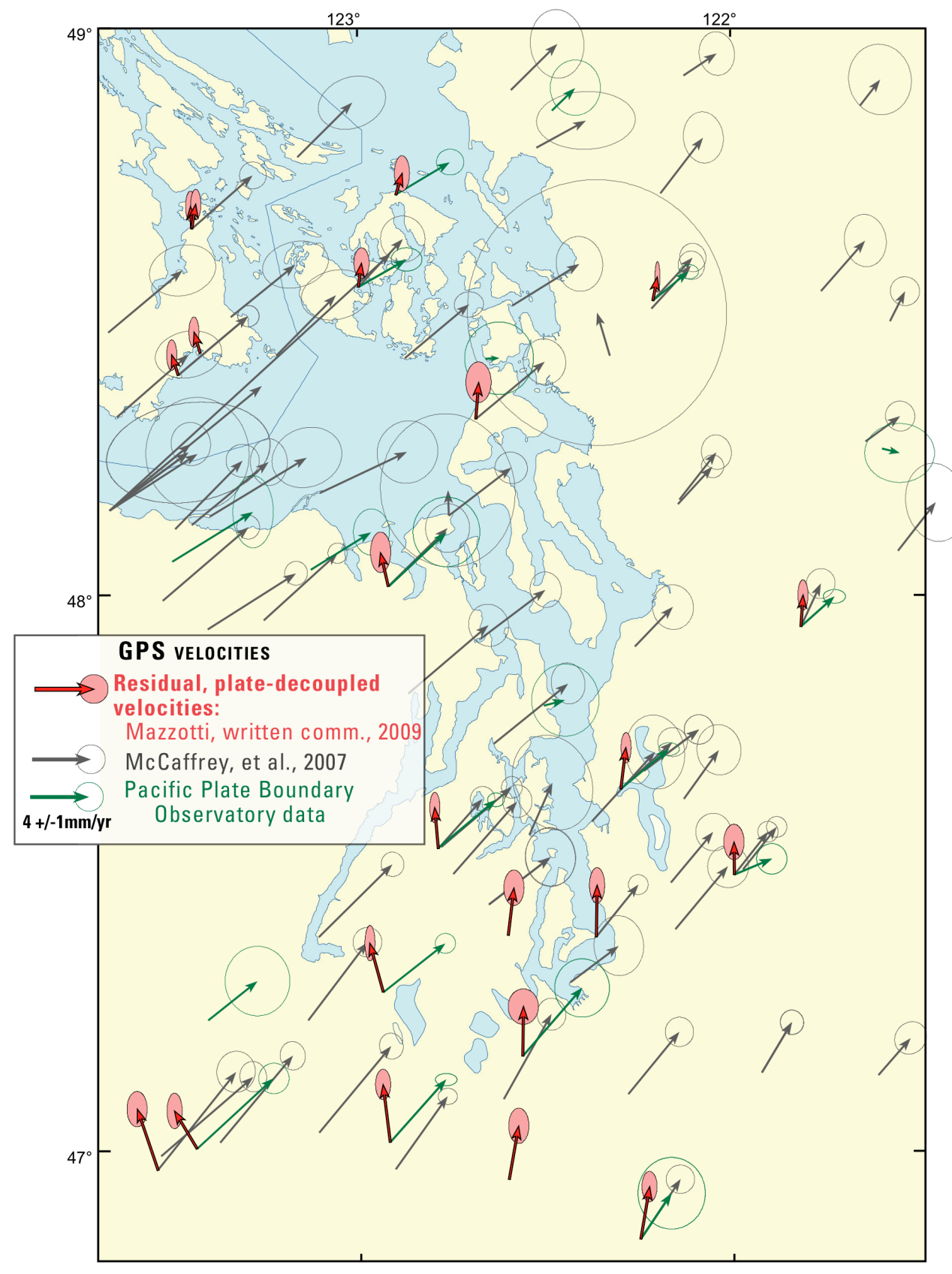

Figure 3. Map showing GPS velocities derived from continuous and campaign survey sites, modified from Mazzotti (written commun., 2009). Black and green arrows predominantly reflect interseismic loading of the Cascadia subduction zone (CSZ) (McCaffrey and others, 2007; Plate Boundary Observatory, 2008). Red arrows are residual GPS velocities of crust after interseismic loading signal of CSZ is removed (Mazzotti and others, 2003; written commun., 2009). Error ellipses are circles at tips of velocity vectors. 


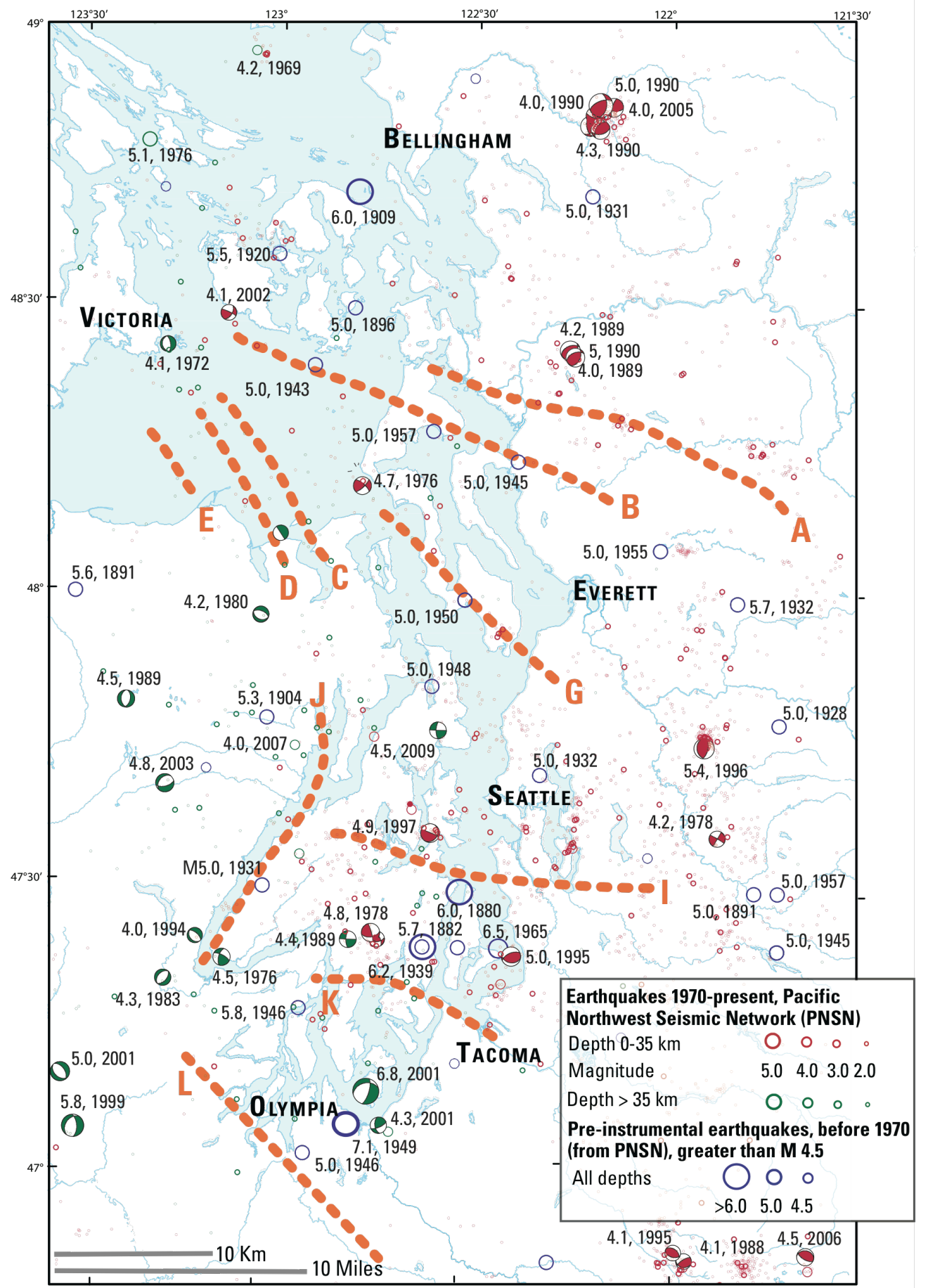

Figure 4. Map showing inferred Quaternary fault structures in Puget Lowland mapped before 1985 (orange dashed lines) from Gower and others (1985); structures are labeled A-L. Shallow earthquakes $(<35 \mathrm{~km})$ denoted by red circles; deep earthquakes $(>35 \mathrm{~km})$ by green circles. Pre-instrumental (earlier than 1970) earthquakes denoted by purple circles. Focal mechanism ("beach ball") color and symbol size corresponds to same depth and magnitude as earthquakes (PNSN, 2008). 


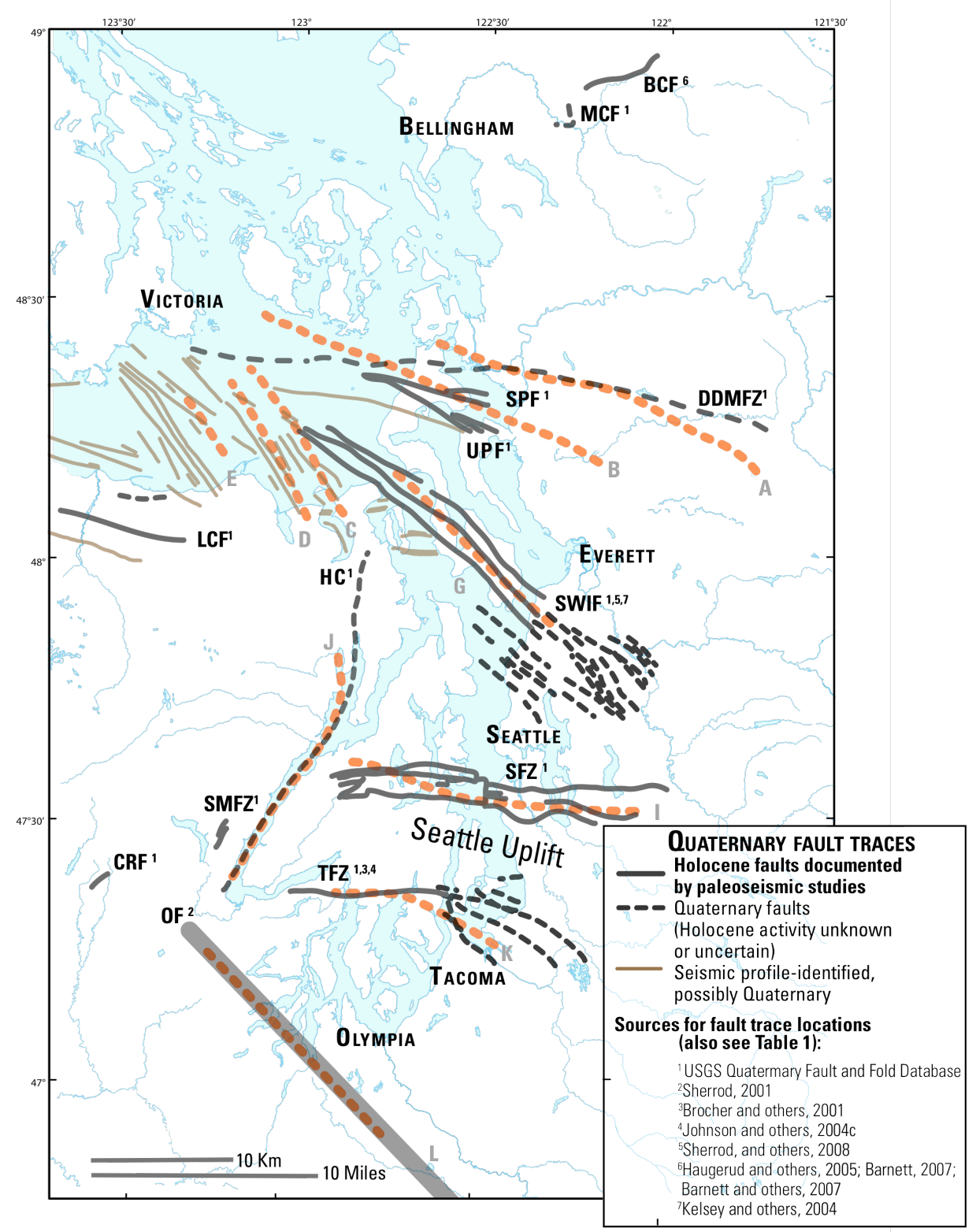

Figure 5. Map showing Quaternary fault traces, including active fault zones, mapped before 2009 in the Puget Lowland, from USGS Quaternary Fault and Fold Database (USGS, 2006) and subsequent studies. Faults that have documented Holocene earthquakes are shown in black; faults that have unknown Holocene activity, but probable activity during Quaternary, in gray. Newly mapped fault traces not included in USGS Quaternary Fault and Fold Database also are shown. Inferred Quaternary fault structures from Gower and others (1985) are denoted by orange dashed lines and labeled in gray. Abbreviations: BCF, Boulder Creek Fault; CRF, Canyon River Fault; DDMFZ, Darrington-Devils Mountain Fault Zone; HC, Hood Canal Fault; LCF, Lake Creek-Boundary Creek Fault; MCF, Macaulay Creek Fault; OF, Olympia Fault; SFZ, Seattle Fault Zone; SMFZ, Saddle Mountain Fault Zone; SPF, Strawberry Point fault; SWIF, South Whidbey Island Fault; TFZ, Tacoma Fault Zone; UPF, Utsalady Point Fault. 


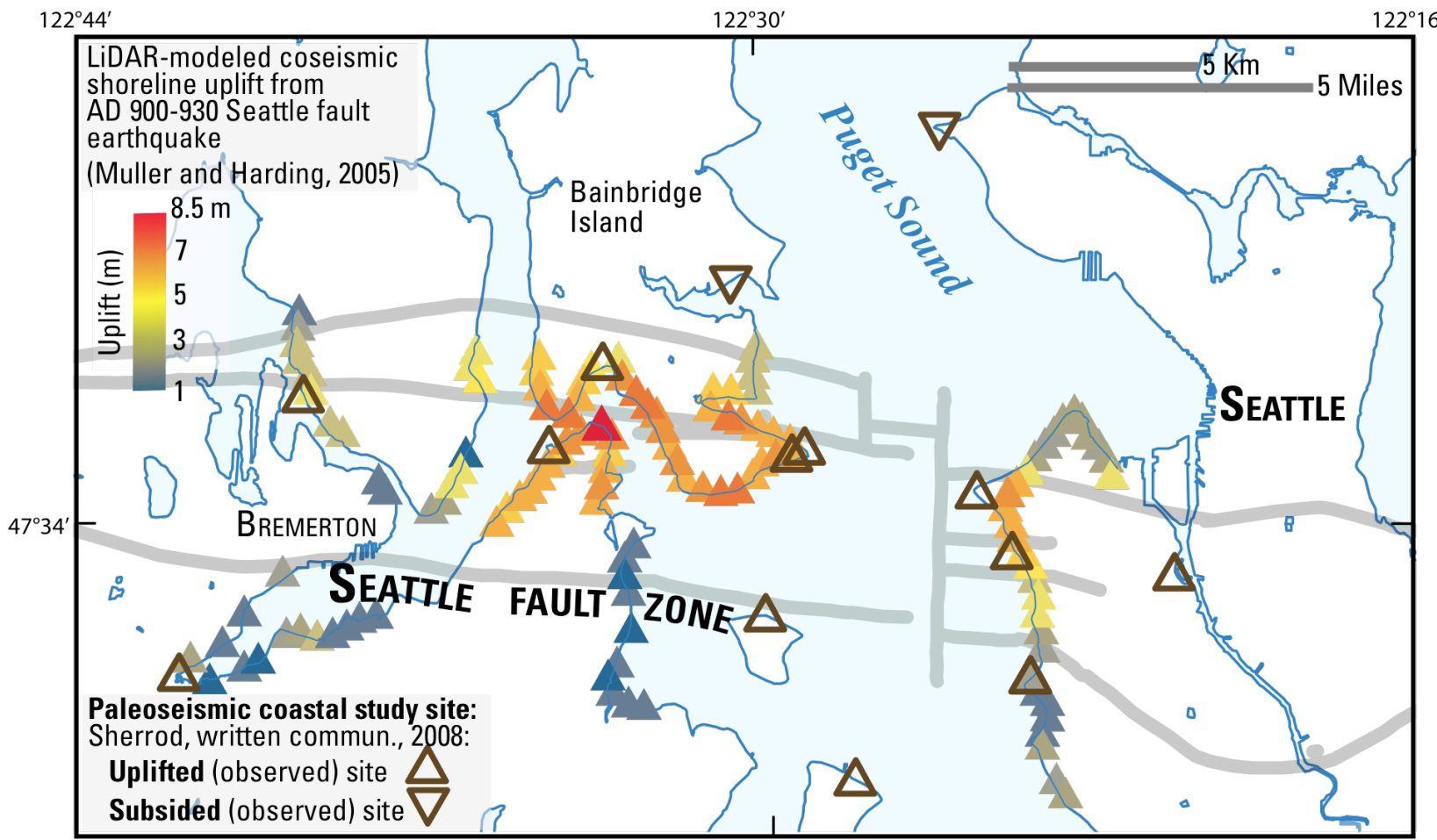

Figure 6. Map showing LiDAR-modeled coseismic shoreline uplift from A.D. 900-930 Seattle Fault earthquake (Muller and Harding, 2005). Colored triangles denote uplift in meters. Open brown triangles mark observed uplift or subsidence from coastal study sites (Sherrod, 2001, 2004b). Seattle Fault Zone traces shown in gray. 


\section{GEOLOGIC DATASETS}

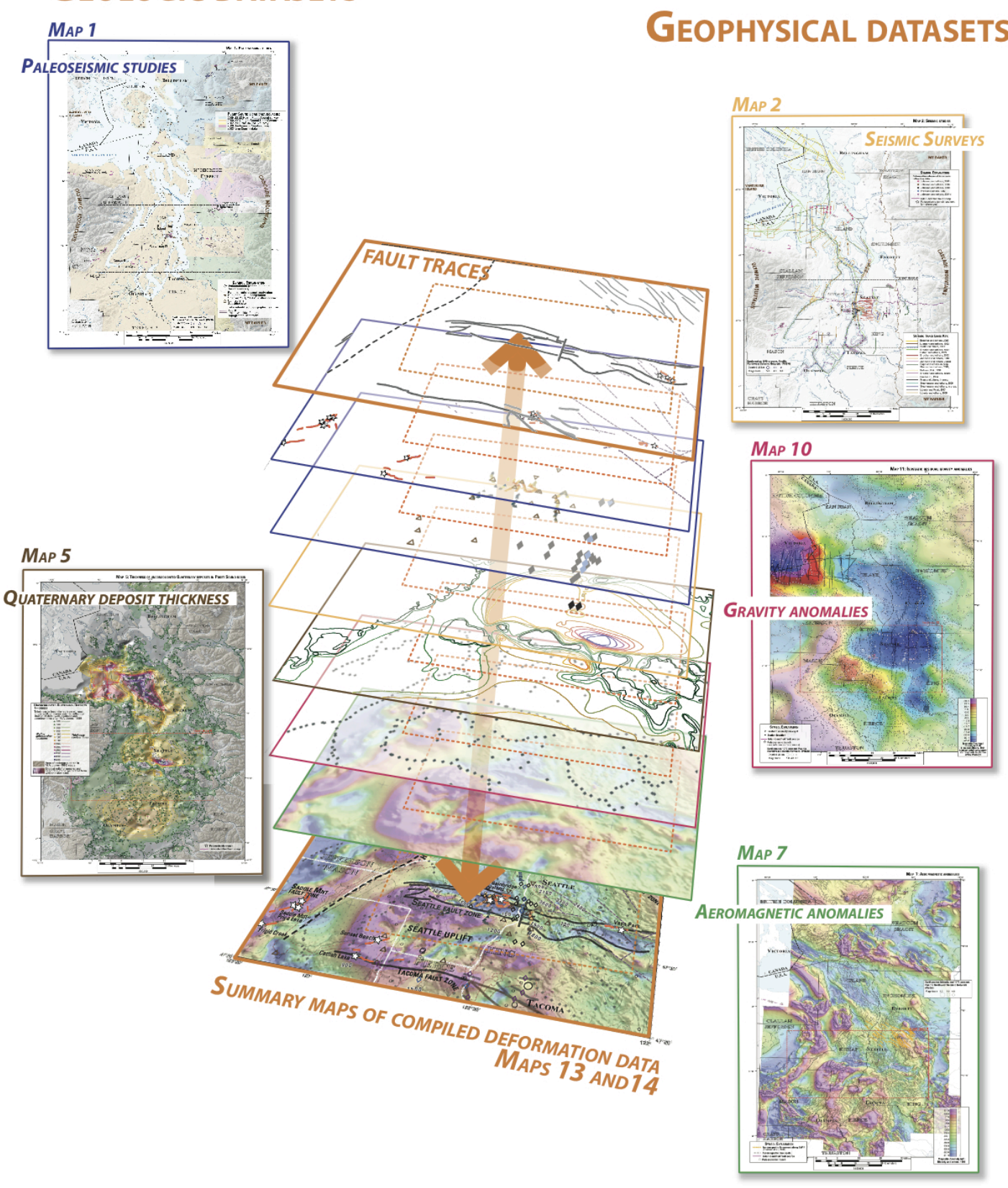

Figure 7. Schematic depiction of how data layers from maps (Maps 1 through 12) have been compiled in summary maps 13 and 14 . Box color links data layers to corresponding maps. Wide array of geological and geophysical data underpins location and characterization of fault zones; for example, location of Seattle Fault Zone (dashed, orange box) is based on evidence from trench excavations, seismic profiles, basin geometry, shoreline deformation, and potential-field anomaly maps. Data layer maps, from top to bottom: fault traces, scarp and trench locations, coastal deformation studies, deformation observed in seismic data, Quaternary deposit thickness, gravity anomalies, aeromagnetic anomalies, and summary map of compiled data layers. 


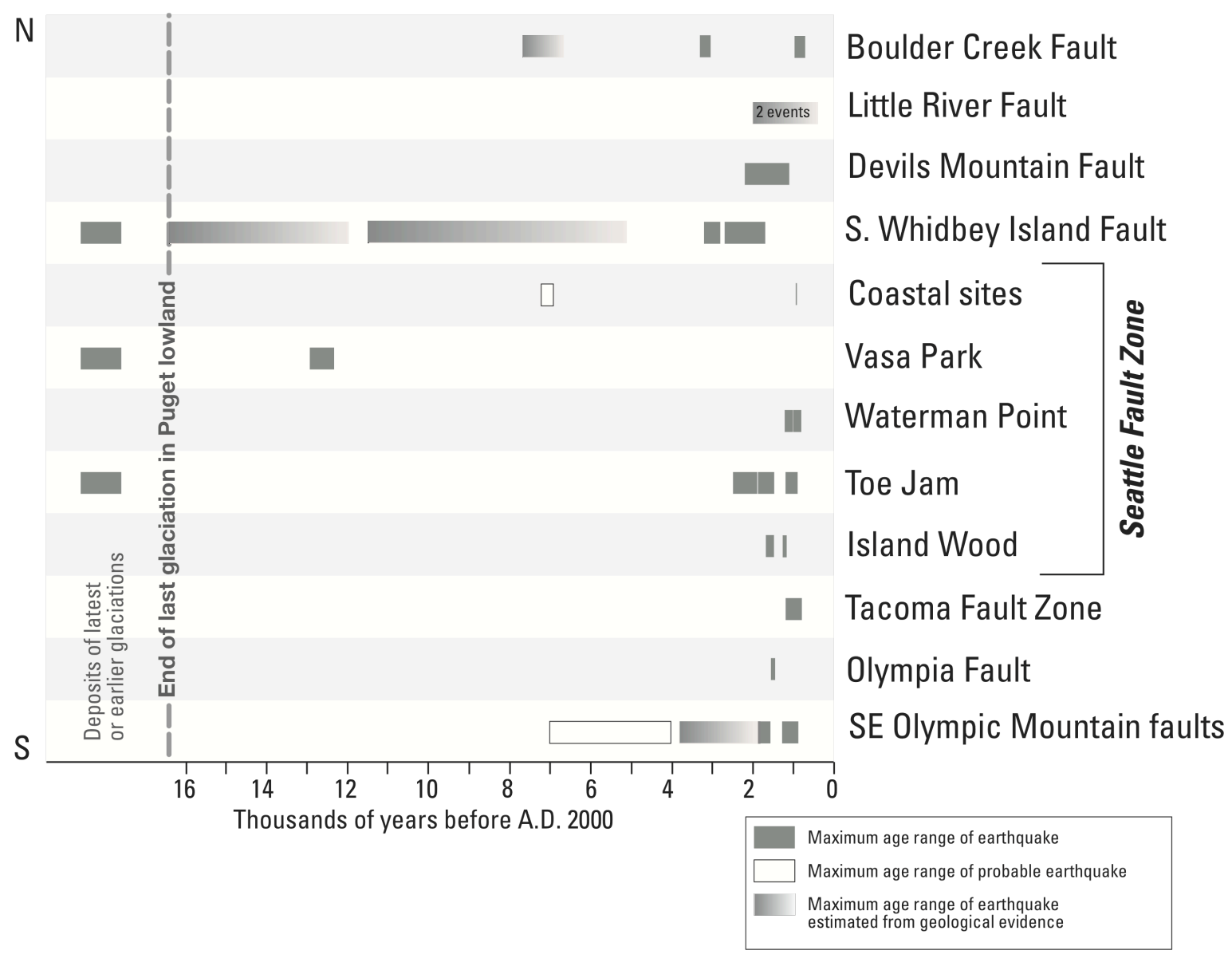

Figure 8. Diagram of known ground-surface deformation in Puget Lowland caused by earthquakes on shallow faults since end of last glaciation. Grey bars denote maximum age range for earthquakes on faults. Data derived from trench excavations, other paleoseismic studies, and dating of faulting-related organic material when possible (Sherrod, written commun., 2008). 


\begin{tabular}{|c|c|c|c|c|c|}
\hline Fault Name (Class) & Paleoseismic studies & $\begin{array}{l}\text { Seismic studies related } \\
\text { to fault }\end{array}$ & $\begin{array}{l}\text { Potential-Field } \\
\text { studies exist for fault } \\
\text { zone location }\end{array}$ & $\begin{array}{l}\text { Lidar data exist for } \\
\text { fault zone location }\end{array}$ & $\begin{array}{l}\text { Other studies including } \\
\text { geologic mapping }\end{array}$ \\
\hline & $\begin{array}{l}\text { Trench excavation }^{1} \\
\text { Paleoecology/shoreline study }\end{array}$ & & $\begin{array}{l}\text { Gravity }^{3} \\
\text { Magnetic }^{4} \\
\end{array}$ & & \\
\hline $\begin{array}{l}\text { Canyon River Fault } \\
\text { (Class A) }\end{array}$ & Walsh and Logan, $2007^{1}$ & & $\begin{array}{l}\text { Finn and others, } 1991^{3} \\
\text { Blakely and others, } 1999^{4}\end{array}$ & & $\begin{array}{l}\text { Tabor and Cady, } 1978 \\
\text { Walsh and Logan, } 1997 \\
\text { Lidke, 2003c } \\
\text { Dragovich and others, } 2002 \\
\text { Babcock and others, } 1992 \\
\end{array}$ \\
\hline $\begin{array}{l}\text { Saddle Mountain Fault } \\
\text { (Class A) }\end{array}$ & 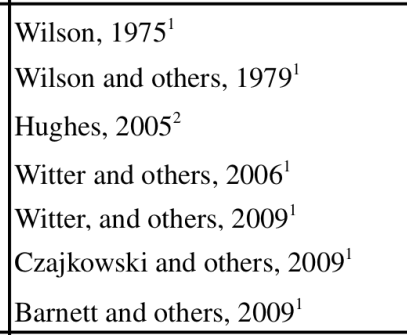 & & $\begin{array}{l}\text { Blakely and others, } 1999^{4} \\
\text { Blakely and others, } 2005^{4} \\
\text { Finn and others, } 1991^{3} \\
\text { Blakely and others, } 2009^{4}\end{array}$ & $\begin{array}{l}\text { Haugerud and others, } 2003 \\
\text { 2000-2007 Puget Sound } \\
\text { Lidar Consortium Survey }\end{array}$ & $\begin{array}{l}\text { Carson, 1970, } 1973 \\
\text { Wilson, 1975 } \\
\text { Tabor and Cady, } 1978 \\
\text { Wilson and others, } 1979 \\
\text { Dragovich and others, } 2002 \\
\text { Lidke, 2003d }\end{array}$ \\
\hline Tacoma Fault (Class A) & $\begin{array}{l}\text { Bucknam and others, } 1992^{2} \\
\text { Sherrod, } 1998^{2} \\
\text { Sherrod, 2001 } 1^{2} \\
\text { Sherrod and others, 2002 } \\
\text { Sherrod and others, 2004a., } \\
\text { Sherrod and others, 2004b } \\
\text { Nelson, } 2007^{1}\end{array}$ & $\begin{array}{l}\text { Pratt and others, } 1997 \\
\text { Brocher and others, } 1999 \\
\text { Brocher and others, } 2001 \\
\text { Johnson and others, } 2004 \mathrm{c} \\
\text { Mitchell and others, } 2008\end{array}$ & $\begin{array}{l}\text { Danes and others, } 1965^{3} \\
\text { Blakely and others, } 1999^{4} \\
\text { Finn and others, } 1991^{3}\end{array}$ & $\begin{array}{l}\text { Haugerud and others, } 2003 \\
\text { 2000-2007 Puget Sound } \\
\text { Lidar Consortium Survey } \\
2003 \text { King County Lidar } \\
\text { survey data }\end{array}$ & $\begin{array}{l}\text { Gower and others, } 1985 \\
\text { Jones, } 1996 \\
\text { Brocher and others, 2004b }\end{array}$ \\
\hline
\end{tabular}




\begin{tabular}{|c|c|c|c|c|c|}
\hline & & & & & Table 1 continued \\
\hline Seattle Fault (Class A) & 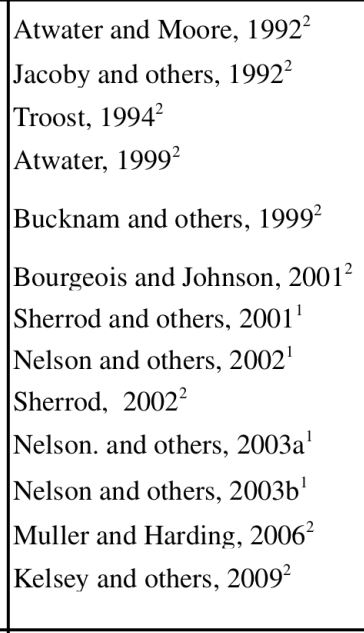 & $\begin{array}{l}\text { Johnson, S. Y. and others, } 1994 \\
\text { Pratt, T.L. and others, } 1997 \\
\text { Johnson and others, } 1999 \\
\text { Fisher and others, } 1999 \\
\text { Brocher and others, 2000a, } \\
\text { 2000b } \\
\text { Brocher and others, 2001 } \\
\text { Calvert and others, 2001 } \\
\text { Brocher and others, 2002 } \\
\text { Brocher and others, 2004a } \\
\text { Johnson and others, 2004c } \\
\text { Liberty and Pratt, 2008 } \\
\text { Pratt, 2008 } \\
\text { Karel and Liberty, } 2008 \\
\text { Liberty and Pratt., } 2008\end{array}$ & $\begin{array}{l}\text { Danes and others, } 1965^{3} \\
\text { Blakely and others, } 1999^{4} \\
\text { Blakely and others, } 2002^{4} \\
\text { Finn and others, } 1991^{3} \\
\text { Anderson and others, } \\
2008^{3,4}\end{array}$ & $\begin{array}{l}\text { Haugerud and others, } 2001 \\
\text { Haugerud. and others, } 2003 \\
\text { Haugerud and Tabor, } 2008 \\
\text { 2000-2007 Puget Sound } \\
\text { Lidar Consortium Survey } \\
2003 \text { King County Lidar } \\
\text { survey data }\end{array}$ & $\begin{array}{l}\text { Gower and others, } 1985 \\
\text { Jones, } 1996 \\
\text { Haeussler and others, } 2000 \\
\text { Booth and others, } 2003 \\
\text { Booth and others, } 2005 \\
\text { Troost and others, } 2005 \\
\text { Johnson, } 2004\end{array}$ \\
\hline $\begin{array}{l}\text { Hood Canal Fault } \\
\text { (Class B) }\end{array}$ & & $\begin{array}{l}\text { Johnson and others, } 1994 \\
\text { Pratt and others, } 1997 \\
\text { Rohwer,1994 } \\
\text { Cuellar, } 1994 \\
\text { Haug,1998 } \\
\end{array}$ & $\begin{array}{l}\text { Danes and others, } 1965^{3} \\
\text { Blakely and others, } 1999^{4} \\
\text { Finn and others, } 1991^{3}\end{array}$ & $\begin{array}{l}\text { 2000-2007 Puget Sound } \\
\text { Lidar Consortium Survey }\end{array}$ & $\begin{array}{l}\text { Gower, H.D. and others, } 1985 \\
\text { Jones, } 1996 \\
\text { Dragovich and others, } 2002 \\
\text { Lidke, 2003a }\end{array}$ \\
\hline $\begin{array}{l}\text { Southern Whidbey } \\
\text { Island Fault Zone } \\
(\text { Class A) }\end{array}$ & $\begin{array}{l}\text { Kelsey, and others, } 2004^{1} \\
\text { Sherrod and others, 2005a } \\
\text { Sherrod and others, } 2005 \mathrm{~b}^{1} \\
\text { Sherrod and others, } 2008^{1}\end{array}$ & $\begin{array}{l}\text { Wagner and Tomson, } 1987 \\
\text { Johnson and others, } 1996 \\
\text { Johnson and others, } 1999\end{array}$ & $\begin{array}{l}\text { Blakely and others, } 1999^{4} \\
\text { Blakely and others, } 2004^{4} \\
\text { Finn and others, } 1991^{3}\end{array}$ & $\begin{array}{l}\text { Haugerud and others, } 2003 \\
\text { 2000-2007 Puget Sound } \\
\text { Lidar Consortium Survey } \\
2003 \text { King County Lidar } \\
\text { survey data }\end{array}$ & $\begin{array}{l}\text { Gower, } 1980 \\
\text { Gower and others, } 1985 \\
\text { Jones, } 1996 \\
\text { Johnson, 2004a }\end{array}$ \\
\hline $\begin{array}{l}\text { Lake Creek-Boundary } \\
\text { Creek Fault/Little River } \\
\text { Fault (Class A) }\end{array}$ & Nelson and others, $2007^{1}$ & & Finn and others, $1991^{3}$ & $\begin{array}{l}\text { Haugerud, } 2002 \\
\text { Haugerud and others, } 2003 \\
\text { 2000-2007 Puget Sound } \\
\text { Lidar Consortium } \\
\end{array}$ & $\begin{array}{l}\text { Brown and others, } 1960 \\
\text { Tabor and Cady, } 1978 \\
\text { Dragovich and others, } 2002 \\
\text { Lidke and others, 2003e }\end{array}$ \\
\hline $\begin{array}{l}\text { Devils Mountain Fault } \\
\text { Zone (Class A) }\end{array}$ & $\begin{array}{l}\text { Dragovich, } 2007^{1} \\
\text { Personius, } 2009^{1}\end{array}$ & Johnson and others, $2001 \mathrm{~b}$ & $\begin{array}{l}\text { Blakely and others, } 1999^{4} \\
\text { Finn and others, } 1991^{3}\end{array}$ & $\begin{array}{l}\text { Haugerud and others, } 2003 \\
\text { 2000-2007 Puget Sound } \\
\text { Lidar Consortium Survey } \\
\text { 2002-2003 NASA/USGS } \\
\text { Lidar Survey }\end{array}$ & $\begin{array}{l}\text { Lovseth, } 1975 \\
\text { Tabor and others, } 1988 \\
\text { Whetten and others, } 1988 \\
\text { Tabor, } 1994 \\
\text { Jones, } 1996\end{array}$ \\
\hline
\end{tabular}


Table 1 continued

Johnson, and others, 2001a

Dragovich and DeOme, 2006

Hayward and others, 2006

Dragovich and Stanton, 2007

\begin{tabular}{|c|c|c|c|c|c|}
\hline $\begin{array}{l}\text { Utsalady Point Fault } \\
\text { (Class A) }\end{array}$ & $\begin{array}{l}\text { Johnson and others, } 2003 \mathrm{a}^{1} \\
\text { Johnson and others, } 2004 \mathrm{~b}^{1}\end{array}$ & Johnson and others, 2001b & $\begin{array}{l}\text { Johnson and others, } \\
2001 b^{3} \\
\text { Blakely and others, } 1999^{4} \\
\text { Finn and others, } 1991^{3} \\
\end{array}$ & $\begin{array}{l}\text { Haugerud and others, } 2003 \\
\text { 2000-2007 Puget Sound } \\
\text { Lidar Consortium Survey }\end{array}$ & $\begin{array}{l}\text { Gower, } 1980 \\
\text { Jones, } 1996 \\
\text { Johnson and others, 2003b }\end{array}$ \\
\hline $\begin{array}{l}\text { Strawberry Point Fault } \\
\text { (Class A) }\end{array}$ & $\begin{array}{l}\text { Johnson and others, } 2003 \mathrm{a}^{1} \\
\text { Johnson and others, } 2004 \mathrm{~b}^{1}\end{array}$ & Johnson and others, $2001 \mathrm{~b}$ & $\begin{array}{l}\text { Blakely and others, } 1999^{4} \\
\text { Finn and others, } 1991^{3}\end{array}$ & $\begin{array}{l}\text { Haugerud and others, } 2003 \\
\text { 2000-2007 Puget Sound } \\
\text { Lidar Consortium Survey }\end{array}$ & $\begin{array}{l}\text { Gower, } 1980 \\
\text { Jones, } 1996 \\
\text { Johnson, } 2001\end{array}$ \\
\hline $\begin{array}{l}\text { Macaulay Fault } \\
\text { (Class B) }\end{array}$ & & & $\begin{array}{l}\text { Blakely and others, } 1999^{4} \\
\text { Finn and others, } 1991^{3}\end{array}$ & $\begin{array}{l}\text { USGS North Puget Sound } \\
\text { Lidar Survey }\end{array}$ & $\begin{array}{l}\text { Misch, P., } 1966 \\
\text { Brown, } 1987 \\
\text { Lidke, 2003b } \\
\text { Qamar, and Zollweg, 1990 } \\
\text { Dragovich and others, 1997a } \\
\text { Dragovich and others, 1997b } \\
\text { Dragovich and others, 2002 }\end{array}$ \\
\hline $\begin{array}{l}\text { Boulder Creek Fault } \\
\text { (not classified in USGS } \\
\text { Quaternary Fault and } \\
\text { Fold database) }\end{array}$ & $\begin{array}{l}\text { Barnett and others, 2006, } 2007^{1,2} \\
\text { Siedlecki, } 2007^{1}\end{array}$ & & $\begin{array}{l}\text { Blakely and others, } 1999^{4} \\
\text { Finn and others, } 1991^{3}\end{array}$ & $\begin{array}{l}\text { Haugerud and others, } 2005 \\
\text { USGS North Puget Sound } \\
\text { Lidar Survey }\end{array}$ & $\begin{array}{l}\text { Misch, } 1966 \\
\text { Johnson, } 1984 \\
\text { Brown, } 1987 \\
\text { Dragovich and others, 1997a } \\
\text { Dragovich and others, 1997b } \\
\text { Dragovich and others, } 2002\end{array}$ \\
\hline $\begin{array}{l}\text { Olympia Fault (not } \\
\text { classified in USGS } \\
\text { Quaternary Fault and } \\
\text { Fold database) }\end{array}$ & $\begin{array}{l}\text { Sherrod, } 2001^{2} \\
\text { Sherrod, } 1998^{2}\end{array}$ & & $\begin{array}{l}\text { Finn and others, } 1991^{3} \\
\text { Blakely and others, } 1999^{4}\end{array}$ & & \\
\hline
\end{tabular}


Table 2: Puget Sound paleoseismic trench studies shown on all maps and inset maps (maps 1-14).

\begin{tabular}{|c|c|c|c|c|c|}
\hline Trench Name & Reference & Associated Fault & $\begin{array}{c}\text { Documented } \\
\text { Holocene faulting }\end{array}$ & Fault type & Offset \\
\hline Canyon River & Walsh and Logan, 2007 & Canyon River Fault & Yes & $\begin{array}{l}\text { Reverse and } \\
\text { left lateral }\end{array}$ & Southeast side up \\
\hline Frigid Creek & Blakely and others, 2009 & Frigid Creek Fault & Yes & Normal & Up to northwest \\
\hline $\begin{array}{l}\text { Saddle Mountain } \\
\text { Fault Zone }\end{array}$ & $\begin{array}{l}\text { Wilson, 1975; Wilson and others, } \\
\text { 1979; Witter and others, 2009; } \\
\text { Czajkowski and others, 2009; } \\
\text { Barnett and others, } 2009\end{array}$ & $\begin{array}{l}\text { Saddle Mountain and Dow Mountain } \\
\text { Faults }\end{array}$ & Yes & $\begin{array}{l}\text { Reverse and } \\
\text { strike slip }\end{array}$ & $\begin{array}{l}\text { Saddle Mountain } \\
\text { East and West faults: } \\
\text { east side up; Dow } \\
\text { Mountain fault: NE } \\
\text { side up }\end{array}$ \\
\hline Catfish Lake & Sherrod and others, 2004a, 2004b & Tacoma Fault & Yes & Reverse & North side up \\
\hline Sunset Beach & Nelson, 2007 & Tacoma Fault & Yes & Normal & Souteast side up \\
\hline Waterman Point & Nelson and others, 2003a & $\begin{array}{l}\text { Waterman Point Fault/Seattle Fault } \\
\text { Zone }\end{array}$ & Yes & Reverse & North side up \\
\hline Bainbridge Island & $\begin{array}{l}\text { Nelson and others, 2002, 2003a, } \\
2003 \mathrm{~b}\end{array}$ & Seattle Fault Zone & Yes & Reverse & North side up \\
\hline Vasa Park & Sherrod, 2002 & Seattle Fault Zone & Yes & Reverse & South side up \\
\hline $\begin{array}{l}\text { Brightwater- } \\
\text { Woodinville }\end{array}$ & $\begin{array}{l}\text { Sherrod and others, 2005a, 2005b, } \\
2008\end{array}$ & Southern Whidbey Island Fault Zone & Yes & Reverse & Northeast side up \\
\hline $\begin{array}{l}\text { Lake Creek- } \\
\text { Boundary Creek }\end{array}$ & Nelson and others, 2007 & Lake Creek-Boundary Creek Fault & Yes & $\begin{array}{l}\text { Oblique and } \\
\text { right and left } \\
\text { lateral }\end{array}$ & \\
\hline Whitman Bench & Dragovich, 2007; Personius, 2009 & Darrington-Devils Mountain Fault Zone & No & & \\
\hline Lake Creek & Personius and others, 2009 & Darrington-Devils Mountain Fault Zone & Yes & Right lateral & \\
\hline Rocky Point & Johnson and others, 2003a, 2004b & Utsalady Point Fault & Yes & $\begin{array}{l}\text { Reverse and } \\
\text { left-lateral }\end{array}$ & Northeast side up \\
\hline $\begin{array}{l}\text { Kendall and } \\
\text { Smuggler }\end{array}$ & $\begin{array}{l}\text { Barnett, 2007; Barnett and others, } \\
\text { 2007; Siedlecki, } 2007\end{array}$ & Boulder Creek Fault & Yes & $\begin{array}{l}\text { Reverse- } \\
\text { oblique }\end{array}$ & South side up \\
\hline
\end{tabular}

